\title{
Open burning of rice, corn and wheat straws: primary emissions, photochemical aging, and secondary organic aerosol formation
}

\author{
Zheng Fang ${ }^{1,3}$, Wei Deng ${ }^{1,3}$, Yanli Zhang ${ }^{1,2}$, Xiang Ding ${ }^{1}$, Mingjin Tang ${ }^{1}$, Tengyu Liu ${ }^{1}$, Qihou Hu ${ }^{1}$, Ming Zhu ${ }^{1,3}$, \\ Zhaoyi Wang ${ }^{1,3}$, Weiqiang Yang ${ }^{1,3}$, Zhonghui Huang ${ }^{1,3}$, Wei Song ${ }^{1,2}$, Xinhui Bi ${ }^{1}$, Jianmin Chen ${ }^{4}$, Yele Sun ${ }^{5}$, \\ Christian George ${ }^{6}$, and Xinming Wang ${ }^{1,2}$ \\ ${ }^{1}$ State Key Laboratory of Organic Geochemistry and Guangdong Key Laboratory of Environment Protection and Resources \\ Utilization, Guangzhou Institute of Geochemistry, Chinese Academy of Sciences, Guangzhou 510640, China \\ ${ }^{2}$ Center for Excellence in Regional Atmospheric Environment, Institute of Urban Environment, \\ Chinese Academy of Sciences, Xiamen 361021, China \\ ${ }^{3}$ University of Chinese Academy of Sciences, Beijing 100049, China \\ ${ }^{4}$ Shanghai Key Laboratory of Atmospheric Particle Pollution and Prevention, Department of Environmental Science \& \\ Engineering, Fudan University, Shanghai 200433, China \\ ${ }^{5}$ Institute of Atmospheric Physics, Chinese Academy of Sciences, Beijing 100029, China \\ ${ }^{6}$ Institut de Recherches sur la Catalyse et l'Environment de Lyon (IRCELYON), CNRS, UMR5256, \\ Villeurbanne 69626, France
}

Correspondence: Xinming Wang (wangxm@gig.ac.cn)

Received: 4 July 2017 - Discussion started: 23 August 2017

Revised: 3 November 2017 - Accepted: 8 November 2017 - Published: 14 December 2017

\begin{abstract}
Agricultural residues are among the most abundant biomass burned globally, especially in China. However, there is little information on primary emissions and photochemical evolution of agricultural residue burning. In this study, indoor chamber experiments were conducted to investigate primary emissions from open burning of rice, corn and wheat straws and their photochemical aging as well. Emission factors of $\mathrm{NO}_{x}, \mathrm{NH}_{3}, \mathrm{SO}_{2}, 67$ non-methane hydrocarbons (NMHCs), particulate matter (PM), organic aerosol (OA) and black carbon (BC) under ambient dilution conditions were determined. Olefins accounted for $>50 \%$ of the total speciated NMHCs emission ( 2.47 to $5.04 \mathrm{~g} \mathrm{~kg}^{-1}$ ), indicating high ozone formation potential of straw burning emissions. Emission factors of PM (3.73 to $\left.6.36 \mathrm{~g} \mathrm{~kg}^{-1}\right)$ and primary organic carbon (POC, 2.05 to $4.11 \mathrm{gC} \mathrm{kg}^{-1}$ ), measured at dilution ratios of 1300 to 4000 , were lower than those reported in previous studies at low dilution ratios, probably due to the evaporation of semi-volatile organic compounds under high dilution conditions. After photochemical aging with an $\mathrm{OH}$ exposure range of $(1.97-4.97) \times 10^{10}$ molecule $\mathrm{cm}^{-3} \mathrm{~s}$ in the chamber, large amounts of secondary organic aerosol (SOA) were produced with OA mass enhancement ratios (the
\end{abstract}

mass ratio of total OA to primary OA) of 2.4-7.6. The 20 known precursors could only explain $5.0-27.3 \%$ of the observed SOA mass, suggesting that the major precursors of SOA formed from open straw burning remain unidentified. Aerosol mass spectrometry (AMS) signaled that the aged OA contained less hydrocarbons but more oxygen- and nitrogencontaining compounds than primary OA, and carbon oxidation state $\left(\mathrm{OS}_{\mathrm{c}}\right)$ calculated with $\mathrm{AMS}$ resolved $\mathrm{O} / \mathrm{C}$ and $\mathrm{H} / \mathrm{C}$ ratios increased linearly $(p<0.001)$ with $\mathrm{OH}$ exposure with quite similar slopes.

\section{Introduction}

On the global scale, biomass burning (BB) is the main source of primary organic carbon (OC) (Bond et al., 2004; Huang et al., 2015), black carbon (BC) (Bond et al., 2013; Cheng et al., 2016), and brown carbon (BrC) (Laskin et al., 2015). It is also the second largest source of non-methane organic gases (NMOGs) in the atmosphere (Yokelson et al., 2008; Stockwell et al., 2014). In addition, atmospheric aging of biomass burning plumes produces substantial secondary pollutants. 
The increase in tropospheric ozone $\left(\mathrm{O}_{3}\right)$ in aged biomass burning plumes could last for days and even months (Thompson et al., 2001; Duncan et al., 2003; Real et al., 2007) with complex atmospheric chemistry (Arnold et al., 2015; Müller et al., 2016). Moreover, biomass and biofuel burning could contribute up to $70 \%$ of the global secondary organic aerosol (SOA) burden (Shrivastava et al., 2015) and hence influence the seasonal variation of global SOA (Tsigaridis et al., 2014). Since it produces large amounts of primary and secondary pollutants, it is essential to characterize primary emissions and photochemical evolution of biomass burning in order to better understand its impacts on air quality (Huang et al., 2014), human health (Alves et al., 2015) and climate change (Andreae et al., 2004; Koren et al., 2004; Laskin et al., 2015; X. Huang et al., 2016).

Open burning of agricultural residues, a convenient and inexpensive way to prepare for the next crop planting, could induce severe regional haze events (Cheng et al., 2013; Tariq et al., 2016). Among all the biomass burning types, agricultural residue burning in the field is estimated to contribute $\sim 10 \%$ of the total mass burned globally (Andreae and Merlet, 2001), and its relative contribution is even larger in Asia $(\sim 34 \%)$, and especially in China (> $60 \%)$ (Streets et al., 2003), where $>600$ million people live in the countryside (NBSPRC, 2015). Agricultural residues burned in China were estimated to be up to 160 million ton in 2012, accounting for $\sim 40 \%$ of the global agricultural residues burned (J. Li et al., 2016). As estimated by Tian et al. (2011), agricultural residue burning contributed $70-80 \%$ of non-methane hydrocarbons (NMHCs) and particulate matter (PM) emitted by biomass burning in China during 2000-2007. A better understanding of the role agricultural residual burning plays in air pollution in China and elsewhere requires better characterization of primary emission and atmospheric aging of emitted trace gases and particles for different types of agricultural residues under different burning conditions.

In the past 2 decades, there have been increasing numbers of characterizations of biomass burning emissions. Andreae and Merlet (2001) summarized emission factors (EFs) for both gaseous and particulate compounds from seven types of biomass burning. Akagi et al. (2011) updated the emission data for 14 types of biomass burning, and newly identified species were included. Since biomass types and combustion conditions may differ in different studies, reported emission factors are highly variable, especially for agricultural residue burning ( $\mathrm{Li}$ et al., 2007, 2009, 2017; Cao et al., 2008; Zhang et al., 2008; Yokelson et al., 2011; Brassard et al., 2014; Sanchis et al., 2014; Wang et al., 2014; Ni et al., 2015; Kim Oanh et al., 2015; Stockwell et al., 2016; Bruns et al., 2017; Tkacik et al., 2017). Moreover, previous studies on agricultural residue burning were mostly carried out near fire spots or in chambers with low dilution ratios. Since biomass burning organic aerosols (BBOAs) are typically semi-volatile (Grieshop et al., 2009b; May et al., 2013), it is expected that measured BBOA emission factors would be affected by dilution processes (Lipsky and Robinson, 2006), and BBOA emission factors under ambient dilution conditions are still unclear. Furthermore, knowledge on NMOGs emitted from agricultural residue burning is very limited. As reported by Stockwell et al. (2015), 21\% (in weight) of NMOGs in biomass burning plumes have not been identified yet. Therefore, comprehensive measurement and characterization of gaseous and particulate species emitted by agricultural residue burning under ambient dilution conditions are urgently needed.

Great attention has been drawn to SOA formation and transformation in biomass burning plumes recently, since a significant increase in mass and apparent change in physicochemical characteristics of aerosols have been observed during atmospheric aging of biomass burning plumes in both field and laboratory studies (Grieshop et al., 2009a, b; Hennigan et al., 2011; Heringa et al., 2011; Lambe et al., 2011; Jolleys et al., 2012; Giordano et al., 2013; Martin et al., 2013; Ortega et al., 2013; Ding et al., 2016a, b, 2017). For agricultural residue burning, evolution processes have not been well characterized yet. To our knowledge, up to now there has only been a chamber study (Li et al., 2015) which has investigated the evolution of aerosol particles emitted by wheat straw burning under dark conditions. Although field studies (Adler et al., 2011; X. X. Liu et al., 2016) witnessed the evolution in mass concentrations, size distribution, oxidation state and optical properties of aerosol particles emitted by agricultural residue burning, these changes could be also influenced by other emission sources and meteorological conditions as well. Since NMOGs emitted by agricultural residue burning are not fully quantified, it is still challenging to predict the concentration and physicochemical properties of SOA that resulted from biomass burning (Spracklen et al., 2011; Jathar et al., 2014; Shrivastava et al., 2015; Hatch et al., 2017). Bruns et al. (2016) suggested that the 22 major NMOGs identified in residential wood combustion could explain the majority of observed SOA, but it remains unclear whether identified NMOGs emitted by agricultural residue burning could fully (or at least largely) explain the SOA formed. In addition, aerosol mass spectrometry (AMS) has been widely used to characterize sources and evolution of ambient OA (Q. Zhang et al., 2011). Although agricultural residue burning is an important type of biomass burning in Asia and especially in China, the lack of AMS spectra for primary and aged OA from agricultural residue burning significantly limits further application of AMS in BBOA research.

In this study, plumes from agricultural residue open burning were directly introduced into a large indoor chamber to firstly characterize primary emissions and then investigate their photochemical evolution under $\sim 25^{\circ} \mathrm{C}$ and $\sim 50 \%$ relative humidity. Corn, rice and wheat straws, which account for more than $90 \%$ of the crop residues burned in China (FAO, 2017), were chosen. A suite of advanced online and offline techniques were utilized to measure gaseous and particulate species, enabling comprehensive measurements of 
emission factors of gaseous and particulate compounds for burning of each type of straw under ambient dilution conditions. In addition, the corresponding formation and transformation of SOA during photochemical aging were investigated using a large indoor smog chamber. This work would help improve our understanding of primary emission, SOA formation and thus environmental impacts of agricultural residue burning.

\section{Materials and methods}

\subsection{Experimental setup}

Photochemical aging was investigated in a smog chamber at the Guangzhou Institute of Geochemistry, Chinese Academy of Sciences (GIG-CAS). The GIG-CAS smog chamber is a $\sim 30 \mathrm{~m}^{3}$ fluorinated ethylene propylene (FEP) reactor housed in a temperature-controlled room. Details of the chamber setup and associated facilities are provided elsewhere (Wang et al., 2014; Liu et al., 2015; Deng et al., 2017). Briefly, 135 black lamps (1.2 m long, $60 \mathrm{~W}$ Philips, Royal Dutch Philips Electronics Ltd, the Netherlands) are used as light sources, giving a $\mathrm{NO}_{2}$ photolysis rate of approximately $0.25 \mathrm{~min}^{-1}$. Two Teflon-coated fans are installed inside the reactor to ensure introduced gaseous and particulate species mixed well within $2 \mathrm{~min}$. Prior to each experiment, the reactor was flushed with the purified dry air at a rate of $100 \mathrm{~L} \mathrm{~min}^{-1}$ for at least $48 \mathrm{~h}$. The compressed indoor air is forced through an air dryer (FXe1; Atlas Copco; Sweden) and a series of gas scrubbers containing activated carbon, Purafil, Hopcalite and allochroic silica gel, followed by a PTFE filter to provide the source of the purified air. The purified dry air contains $<1 \mathrm{ppb} \mathrm{NO}_{x}, \mathrm{O}_{3}$ and carbonyl compounds, $<5$ ppb NMHCs and no detectable particles with relative humidity $<5 \%$.

Corn, rice and wheat straws were collected from Henan, Hunan and Guangdong provinces, respectively. Since moisture content in straws would affect emission factors of atmospheric pollutants (Sanchis et al., 2014; Ni et al., 2015), all the agricultural residues used in this study were dried in a stove at $80^{\circ} \mathrm{C}$ for $24 \mathrm{~h}$ before being burned. After baking, the water content in the crop residues was less than $1 \%$. The water content of crop residues was measured by using the method recommended by Liao et al. (2004). Straws were weighed before and after baking in a stove at $105^{\circ}$ for $24 \mathrm{~h}$, and the difference in weights was calculated to be the weight of the water in the crop residues. Water content was the quotient of the water weight and the whole weight of the straws. In each experiment, $\sim 300 \mathrm{~g}$ straws were burned and the burning typically lasted for 3-5 min. Straws were ignited by a butane-fueled lighter and burned under open field burning conditions. The resulting smoke was collected by an inverted funnel and introduced into the chamber using an oilfree pump (Gast Manufacturing, Inc, USA) at a flow rate of $\sim 15 \mathrm{~L} \mathrm{~min}^{-1}$ through a $5.5 \mathrm{~m}$ long copper tube (inner di- ameter: $3 / 8 \mathrm{inch}$ ), and the residence time in the tube was estimated to be $<2 \mathrm{~s}$. Before each experiment, the transfer tube was pre-flushed for $15 \mathrm{~min}$ with ambient air and $2 \mathrm{~min}$ with smokes (not introduced into the chamber reactor). During the whole process, the tube was heated at $80^{\circ} \mathrm{C}$ to reduce the losses of organic vapors. Based on the volumes of the smoke introduced and the chamber reactor, the dilution ratios were estimated to be $1300-4000$, falling into the typical range (1000-10000) under ambient dilution conditions (Robinson et al., 2007). After being characterized in the dark for $>20 \mathrm{~min}$, black lamps were turned on and the diluted smokes were photochemically aged for $5 \mathrm{~h}$. At the end, the black lamps were switched off and the aged aerosols were characterized in the next $1 \mathrm{~h}$ to determine the particle wall loss. The particle size evolved through the course of photooxidation, and the differences in particle wall-loss rates during photoreaction and after the lamps were off brought about by the size evolving are estimated to be within $\pm 9 \%$ (Fig. S1 in the Supplement).

In total 20 experiments were conducted ( 9 for rice straw, 6 for corn straw and 5 for wheat straw), among which 14 experiments were conducted only in the dark to measure primary emissions and 6 experiments were carried out both in the dark and under irradiation to investigate photochemical evolution of open straw burning emissions. Tables 1 and 2 summarize important experimental conditions and key results for all the experiments.

\subsection{Instrumentation}

Commercial instruments were used for online monitoring of $\mathrm{NO}_{x}$ (EC9841T, Ecotech, Australia), $\mathrm{NH}_{3}$ (Model 911-0016, Los Gatos Research, USA) and $\mathrm{SO}_{2}$ (Model 43i, Thermo Scientific, USA). $\mathrm{CH}_{4}$ and $\mathrm{CO}$ were analyzed offline using gas chromatography (Agilent 6980GC, USA) coupled with a flame ionization detector and a packed column (5A molecular sieve 60/80 mesh, $3 \mathrm{~m} \times 1 / 8$ inch) (Zhang et al., 2012), and $\mathrm{CO}_{2}$ was analyzed using a HP $4890 \mathrm{D}$ gas chromatograph (Yi et al., 2007). The detection limits were all less than $30 \mathrm{ppbv}$ for $\mathrm{CH}_{4}, \mathrm{CO}$ and $\mathrm{CO}_{2}$. The relative standard deviations (RSDs) of $\mathrm{CO}$ and $\mathrm{CO}_{2}$ measurements were both less than $3 \%$ based on seven duplicate injection of $1.0 \mathrm{ppmv}$ standards (Spectra Gases Inc, USA). Volatile organic compounds (VOCs) were continuously measured using a proton-transferreaction time-of-flight mass spectrometer (PTR-TOF-MS; Model 2000, Ionicon Analytik GmbH, Austria). Calibration of the PTR-TOF-MS was performed every few weeks using a certified custom-made standard mixture of VOCs (Ionicon Analytik Gmbh, Austria) that were dynamically diluted to six levels $(2,5,10,20,50$ and $100 \mathrm{ppbv})$. Methanol, acetonitrile, acetaldehyde, acrolein, acetone, isoprene, crotonaldehyde, 2-butanone, benzene, toluene, o-xylene, chlorobenzene and $\alpha$-pinene were included in the calibration mixture. Their sensitivities, indicated by the ratio of the normalized counts per second to the concentration levels of the VOCs 
in ppbv, were used to convert the raw PTR-TOF-MS signal to concentration (Z. Huang et al., 2016). Quantification of the compounds that were not included in the mixture was performed by using calculated mass-dependent sensitivities based on the measured sensitivities (Stockwell et al., 2015). Mass-dependent sensitivities were linearly fitted for oxygencontaining compounds and the remaining compounds separately. The decay of toluene measured by PTR-TOF-MS was used to derive the $\mathrm{OH}$ radical concentrations for every $2 \mathrm{~min}$ during each experiment, and the $\mathrm{OH}$ exposure was calculated as the product of the $\mathrm{OH}$ concentration and the time interval. Continuous monitoring of 20 SOA precursors (including 9 NMHCs and 11 oxygen-containing VOCs) from PTR-TOF-MS provided us with data to do the SOA prediction discussed in the Sects. 2.3.5 and 3.3.2. Air samples were also collected from the chamber reactor using $2 \mathrm{~L}$ electropolished stainless-steel canisters before and after smoke injection. In total $67 \mathrm{C}_{2}-\mathrm{C}_{12}$ NMHCs were measured (Table S1 in the Supplement) using an Agilent 5973N gas chromatography mass-selective detector/flame ionization detector (GCMSD/FID; Agilent Technologies, USA) coupled to a Preconcentrator (Model 7100, Entech Instruments Inc., USA), and analytical procedures have been detailed elsewhere (Wang and $\mathrm{Wu}, 2008$; Zhang et al., 2010, 2012). Results from GCMSD/FID were used to quantify the emission factors of 67 NMHCs discussed in the Sect. 3.1.

Particle number/volume concentrations and size distribution were measured with a scanning mobility particle sizer (SMPS; Classifier model 3080, CPC model 3775, TSI Incorporated, USA). The SMPS was operated with a sheath flow of $3.0 \mathrm{~L} \mathrm{~min}^{-1}$ and a sampling flow of $0.3 \mathrm{~L} \mathrm{~min}^{-1}$, allowing for a size scanning range of 14 to $760 \mathrm{~nm}$ within 255 s. A high-resolution time-of-flight aerosol mass spectrometer (HR-TOF-AMS; Aerodyne Research Incorporated, USA) was used to measure chemical compositions of nonrefractory aerosols (DeCarlo et al., 2006). The HR-ToF-AMS was operated by alternating every other minute between the high sensitivity $\mathrm{V}$ mode and the high-resolution $\mathrm{W}$ mode. Toolkit Squirrel 1.57I was used to obtain real-time concentration variations of sulfate, nitrate, ammonium, chloride and organics, and toolkit Pika 1.16I was used to determine the detailed compositions of OA (Aiken et al., 2007, 2008; Canagaratna et al., 2015). The AMS signal at $m / z 44$ was corrected for the contribution from gaseous $\mathrm{CO}_{2}$. The ionization efficiency of the AMS was calibrated routinely by measuring $300 \mathrm{~nm}$ monodisperse ammonium nitrate aerosols. Considering the underestimation of particulate matter by the AMS, aerosol mass measured by AMS was corrected with the data from the SMPS and the aethalometer. Conductive silicon tubes were used for aerosol sampling to reduce electrostatic losses of particles.

$\mathrm{BC}$ was measured with a seven-channel aethalometer (Model AE-31, Magee Scientific, USA). Cheng et al. (2016) measured the mass absorption efficiency (MAE) of BC from biomass burning at wavelengths of 532 and $1047 \mathrm{~nm}$, respec- tively, and the absorption Ängström exponents (AAEs) were estimated to be in the range of 0.9-1.1. Based on the relationship between MAE and wavelength, a MAE value of $4.7 \mathrm{~m}^{2} \mathrm{~g}^{-1}$ was calculated for $880 \mathrm{~nm}$ by assuming the AAE to be 1.0. The MAE value was then applied to convert absorption data in $880 \mathrm{~nm}$ to $\mathrm{BC}$ mass concentrations. Aethalometer attenuation measurements were corrected for particle loading effects and the scattering of filter fibers using the method developed by Kirchstetter and Novakov (2007) and Schmid et al. (2006).

\subsection{Data analysis}

\subsubsection{Particle effective density}

Assuming that particles are spherical and non-porous, the effective density ( $\left.\rho_{\text {eff }}\right)$ can be estimated by Eq. (1) (DeCarlo et al., 2004; Schmid et al., 2007):

$\rho_{\mathrm{eff}}=\rho_{0} \cdot \frac{d_{\mathrm{va}}}{d_{\mathrm{m}}}$,

where $\rho_{0}$ is the standard density $\left(1.0 \mathrm{~g} \mathrm{~cm}^{-3}\right)$, and $d_{\mathrm{va}}$ and $d_{\mathrm{m}}$ are the AMS-measured vacuum aerodynamic diameter and SMPS-measured mobility diameter. The input diameters to this equation were determined by comparing distributions of vacuum aerodynamic and electric mobility diameters, using the AMS and SMPS, respectively. Derived $\rho_{\text {eff }}$ was used to convert volume concentrations of aerosol particles measured by the SMPS to mass concentrations.

\subsubsection{Emission factors and modified combustion efficiency}

The carbon mass balance approach (Ward et al., 1992; Andreae and Merlet, 2001) was used to calculate fuel-based emission factors (EFs) for each compound $\left(\mathrm{g} \mathrm{kg}^{-1}\right.$ dry fuel). The emission factor for the $i$ th species, $\mathrm{EF}_{i}$, is calculated by Eq. (2):

$\mathrm{EF}_{i}=\frac{m_{i} \cdot \mathrm{EF}_{\mathrm{C}}}{\Delta\left[\mathrm{CO}_{2}\right]+\Delta[\mathrm{CO}]+\Delta\left[\mathrm{PM}_{\mathrm{C}}\right]+\Delta[\mathrm{HC}]}$,

where $m_{i}$ is the concentration $\left(\mathrm{g} \mathrm{m}^{-3}\right)$ of the $i$ th species; $\Delta\left[\mathrm{CO}_{2}\right], \Delta[\mathrm{CO}]$, and $\Delta[\mathrm{HC}]$ are the background-corrected carbon mass concentration $\left(\mathrm{g} \mathrm{C} \mathrm{m}^{-3}\right)$ of the $\mathrm{CO}_{2}, \mathrm{CO}$, and speciated hydrocarbons, respectively; $\Delta\left[\mathrm{PM}_{\mathrm{C}}\right]$ is the background-corrected carbon in the particle phase $\left(\mathrm{g} \mathrm{C} \mathrm{m}^{-3}\right)$; and $\mathrm{EF}_{\mathrm{C}}$ is the emission factor of carbon into the air determined by elemental and gravitational analyses, given by Eq. (3):

$\mathrm{EF}_{\mathrm{C}}=\frac{m_{\text {fuel }} \cdot \omega_{\text {fuel }}-m_{\mathrm{ash}} \cdot \omega_{\mathrm{ash}}}{m_{\text {fuel }}}$,

where $\omega_{\text {fuel }}$ and $\omega_{\text {ash }}$ are mass fractions of carbon in the dry fuel and its ash, and $m_{\text {fuel }}$ and $m_{\text {ash }}$ are the mass of dry fuel 
Table 1. Primary emission factors measured for agricultural residue burning. All the units are $\mathrm{g} \mathrm{kg}^{-1}$, except that the unit for particle number (PN) is $10^{15}$ particle $\mathrm{kg}^{-1}$. MCE: modified combustion efficiency; NMHCs: non-methane hydrocarbons; POA: primary organic aerosol; POC primary organic carbon; BC: black carbon.

\begin{tabular}{|c|c|c|c|c|c|c|}
\hline \multirow[b]{2}{*}{ Species } & \multicolumn{2}{|c|}{ Rice } & \multicolumn{2}{|c|}{ Corn } & \multicolumn{2}{|c|}{ Wheat } \\
\hline & This study $(n=9)$ & Others & This study $(n=6)$ & Others & This study $(n=5)$ & Others \\
\hline MCE & $0.926 \pm 0.049$ & & $0.953 \pm 0.019$ & & $0.949 \pm 0.035$ & \\
\hline $\mathrm{CO}_{2}$ & $1262 \pm 81$ & & $1477 \pm 28$ & & $1423 \pm 60$ & \\
\hline $\mathrm{CO}$ & $63.5 \pm 41.4$ & & $46.1 \pm 19.2$ & & $48.6 \pm 33.0$ & \\
\hline $\mathrm{NO}_{x}$ & $1.47 \pm 0.61$ & $3.51 \pm 0.38^{\mathrm{a}}$ & $5.00 \pm 3.94$ & $4.3 \pm 1.8^{b}$ & $3.08 \pm 0.93$ & $\begin{array}{r}3.3 \pm 1.7^{\mathrm{b}} \\
2.27 \pm 0.04^{\mathrm{a}}\end{array}$ \\
\hline $\mathrm{NH}_{3}$ & $0.45 \pm 0.15$ & $\begin{array}{c}0.95 \pm 0.65^{\mathrm{a}} \\
4.10 \pm 1.24^{\mathrm{c}}\end{array}$ & $0.63 \pm 0.30$ & $0.68 \pm 0.52^{b}$ & $0.22 \pm 0.19$ & $\begin{array}{r}0.37 \pm 0.14^{\mathrm{b}} \\
0.21 \pm 0.14^{\mathrm{a}}\end{array}$ \\
\hline $\mathrm{SO}_{2}$ & $0.07 \pm 0.07$ & $\begin{array}{c}0.18 \pm 0.31^{\mathrm{d}} \\
0.37 \pm 0.27^{\mathrm{e}} \\
1.27 \pm 0.35^{\mathrm{a}}\end{array}$ & $0.99 \pm 1.53$ & $0.04 \pm 0.04^{\mathrm{d}}$ & $0.72 \pm 0.34$ & $\begin{array}{c}0.04 \pm 0.04^{\mathrm{d}} \\
0.73 \pm 0.15^{\mathrm{a}}\end{array}$ \\
\hline NMHCs & $5.04 \pm 2.04$ & $1.25^{\mathrm{f}}$ & $2.47 \pm 2.11$ & $1.59 \pm 0.43^{\mathrm{g}}$ & $3.08 \pm 2.43$ & $\begin{array}{r}1.69 \pm 0.58^{\mathrm{g}} ; \\
0.90^{\mathrm{f}}\end{array}$ \\
\hline PM & $3.73 \pm 3.28$ & $\begin{array}{r}8.5 \pm 6.7^{\mathrm{h}} \\
8.3 \pm 2.2^{\mathrm{e}} \\
13.2 \pm 1.44^{\mathrm{i}} \\
4.2^{\mathrm{c}}\end{array}$ & $5.44 \pm 3.43$ & $\begin{array}{l}12.2 \pm 5.4^{\mathrm{h}} \\
11.7 \pm 1.0^{\mathrm{b}} \\
5.36 \pm 0.55^{\mathrm{i}}\end{array}$ & $6.36 \pm 2.98$ & $\begin{array}{r}11.4 \pm 4.9^{\mathrm{h}} \\
7.6 \pm 4.1^{\mathrm{b}} \\
5.30 \pm 0.30^{\mathrm{i}}\end{array}$ \\
\hline PN & $2.94 \pm 0.91$ & $0.018 \pm 0.001^{\mathrm{j}}$ & $7.29 \pm 4.17$ & $0.017 \pm 0.001^{\mathrm{j}}$ & $5.87 \pm 2.89$ & $0.010 \pm 0.001^{\mathrm{j}}$ \\
\hline POA & $2.99 \pm 1.00$ & & $3.99 \pm 2.68$ & & $5.96 \pm 0.19$ & \\
\hline POC & $2.05 \pm 0.72$ & $\begin{array}{r}3.3 \pm 2.8^{\mathrm{h}} \\
6.02 \pm 0.60^{\mathrm{i}}\end{array}$ & $2.52 \pm 1.66$ & $\begin{array}{r}6.3 \pm 3.6^{\mathrm{h}} \\
3.9 \pm 1.7^{\mathrm{b}} \\
2.06 \pm 0.34^{\mathrm{i}}\end{array}$ & $4.11 \pm 0.29$ & $\begin{array}{r}5.1 \pm 3.0^{\mathrm{h}} \\
2.7 \pm 1.0^{\mathrm{b}} \\
2.42 \pm 0.13^{\mathrm{i}}\end{array}$ \\
\hline $\mathrm{BC}$ & $0.22 \pm 0.11$ & $0.21 \pm 0.13^{h}$ & $0.24 \pm 0.09$ & $\begin{array}{c}0.28 \pm 0.09^{\mathrm{h}} \\
0.35 \pm 0.10^{\mathrm{b}}\end{array}$ & $0.27 \pm 0.07$ & $\begin{array}{c}0.24 \pm 0.12^{\mathrm{h}} \\
0.49 \pm 0.12^{\mathrm{b}}\end{array}$ \\
\hline
\end{tabular}

${ }^{\mathrm{a}}$ Stockwell et al. (2015); ${ }^{\mathrm{b}} \mathrm{Li}$ et al. (2007), PM corresponds to $\mathrm{PM}_{2.5} ;{ }^{\mathrm{c}}$ Christian et al. (2010); ${ }^{\mathrm{d}}$ Cao et al. (2008); ${ }^{\mathrm{e}}$ Kim Oanh et al. (2015), PM corresponds to PM 2.5 ; ${ }^{\mathrm{f}}$ Wang et al. (2014), 56 NMHCs species summarized; ${ }^{\mathrm{g}} \mathrm{Li}$ et al. (2009), $52 \mathrm{NMHCs}$ species summarized; ${ }^{\mathrm{h}} \mathrm{Ni}$ et al. (2015), PM corresponds to PM $2.5{ }^{\mathrm{i}}{ }^{\mathrm{Li}}$ et al. (2017), $\mathrm{PM}$ corresponds to $\mathrm{PM}_{1} ;{ }^{\mathrm{j}}$ Zhang et al. (2008).

and its ash. The modified combustion efficiency (MCE) is defined by Eq. (4) (Heringa et al., 2011; Hennigan et al., 2011; Ni et al., 2015):

$\mathrm{MCE}=\frac{\Delta\left[\mathrm{CO}_{2}\right]}{\Delta\left[\mathrm{CO}_{2}\right]+\Delta[\mathrm{CO}]}$.

\subsubsection{Ozone formation potential}

The ozone formation potential (OFP) of the speciated NMHCs was calculated from the emission factor and maximum incremental reactivity (MIR) of each individual NMHC, using Eq. (5):

$\mathrm{OFP}=\sum_{i=1}^{n}\left(\mathrm{EF}_{i} \cdot \mathrm{MIR}_{i}\right)$

where OFP is the ozone formation potential of NMHCs emitted per unit of biomass (unit: $\mathrm{g} \mathrm{kg}^{-1}$ ), and $\mathrm{MIR}_{i}$ is the MIR of the $i$ th NMHC (unit: $\mathrm{g} \mathrm{O}_{3} \mathrm{~g} \mathrm{NHMC}^{-1}$ ) (Carter, 2008).

\subsubsection{Wall-loss corrections}

Due to the loss of particles and vapors to chamber walls, measured data in chamber studies need to be corrected for wall loss. For this purpose, in our study $1 \mathrm{~h}$ dark decay of aged aerosols was undertaken after photochemical aging was terminated. The loss of particles on the chamber wall is a first-order process (McMurry and Grosjean, 1985). The wallloss rates of AMS-measured organics, sulfate, nitrate, chloride and ammonium were determined using the dark decay data and were applied to wall-loss correction for the entire experiment. By assuming that the condensed materials on the wall remain completely in equilibrium with the gas phase, we used the $\omega=1$ case to correct the OA mass, where $\omega$ is a proportionality factor of organic vapor partitioning to chamber walls and suspended particles (Weitkamp et al., 2007; Henry et al., 2012). For SMPS measurements, the number concentration in each size channel (110 channels in total) was corrected for wall loss separately, since wall-loss rates of aerosol particles are size-dependent (Takekawa et al., 2003). 


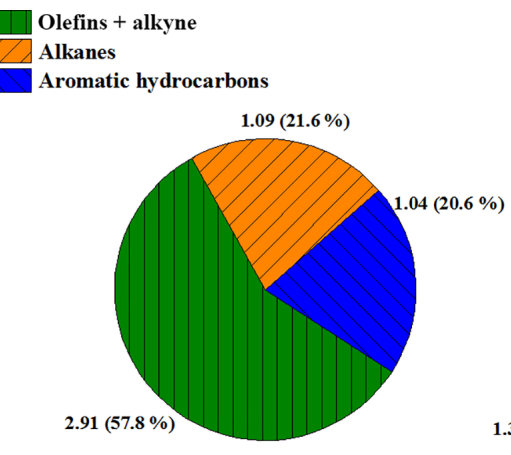

(a) Rice, 5.04 in total

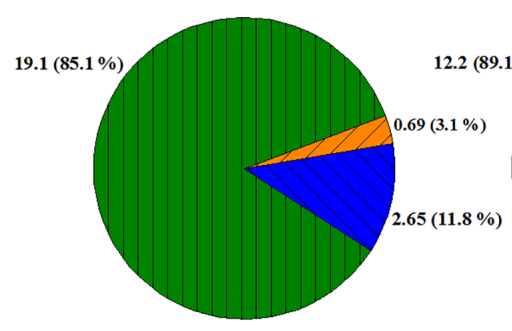

(d) Rice, 22.5 in total

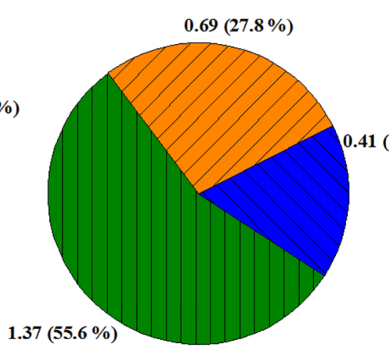

(b) Corn, 2.46 in total

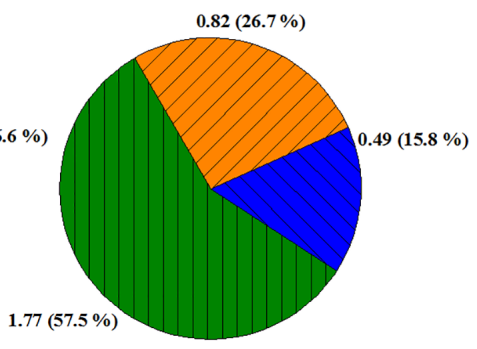

(c) Wheat, 3.08 in total

Figure 1. (a-c) Non-methane hydrocarbon (NMHC) compositions and (d-f) their relative contribution to ozone formation potential (OFP) for open burning of rice, corn and wheat straw.

\subsubsection{OA production prediction}

In this study, 20 NMOGs which have been used to estimate SOA yields by previous work (Ng et al., 2007; Chan et al., 2009, 2010; Hildebrandt et al., 2009; Gómez Alvarez et al., 2009; Shakya and Griffin, 2010; Chhabra et al., 2011; Nakao et al., 2011; Borras and Tortajada-Genaro, 2012; Yee et al., 2013; Lim et al., 2013) were quantified using PTR-TOF-MS, and the applied SOA yields are summarized in Table S2. The mass concentration of SOA ([SOA $]_{\text {predicted }}, \mu \mathrm{g} \mathrm{m}^{-3}$ ) formed from these 20 precursors can be estimated using Eq. (6):

$[\mathrm{SOA}]_{\text {predicted }}=\sum_{i}\left(\Delta\left[X_{i}\right] \cdot Y_{i}\right)$,

where $\Delta\left[X_{i}\right]\left(\mu \mathrm{g} \mathrm{m}^{-3}\right)$ is the reacted amount of the $i$ th gasphase precursor and $Y_{i}$ is the corresponding SOA yield.

Assuming that primary OA (POA) levels stayed constant during aging processes, the mass concentration of SOA formed could be estimated as the difference in OA mass concentrations before and after photochemical aging. It should be noted that POA would decrease during aging processes (Tiitta et al., 2016), probably leading to the underestimation of the formed SOA. In papers where those SOA yields were borrowed from, no organic vapor wall loss was accounted for when calculating the mass concentration of the formed SOA, so the same wall-loss correction method was used when comparing the predicted SOA and the formed SOA.

\section{Results and discussion}

\subsection{Emissions of gaseous pollutants}

Table 1 compares emission factors of gaseous and particulate species measured in our and previous studies. In our study, the emission factors of $\mathrm{NO}_{x}$ were $1.47 \pm 0.61,5.00 \pm 3.94$, and $3.08 \pm 0.93 \mathrm{~g} \mathrm{~kg}^{-1}$ for rice, corn, and wheat straw, and $\mathrm{NO}$ accounted for $84 \pm 11 \%$ of $\mathrm{NO}_{x}$ primary emission for all experiments. Emission factors of $\mathrm{NH}_{3}$ were measured to be $0.45 \pm 0.15,0.63 \pm 0.30$ and $0.22 \pm 0.19 \mathrm{~g} \mathrm{~kg}^{-1}$ for rice, corn and wheat straw. Our measured emission factors of reactive nitrogen species were comparable to those reported by previous studies (Li et al., 2007; Tian et al., 2011). Emission factors of $\mathrm{SO}_{2}$ were $0.07 \pm 0.07,0.99 \pm 1.53$ and $0.72 \pm 0.34 \mathrm{~g} \mathrm{~kg}^{-1}$ for rice, corn and wheat straw. Our measured emission factors of $\mathrm{SO}_{2}$ were lower than those reported by Cao et al. (2008) and Kim Oanh et al. (2015) for rice straw, but higher than those reported by Cao et al. (2008) for corn and wheat straw. Due to low sulfur contents in crop straws, the $\mathrm{SO}_{2}$ emission factors for open burning of crop residues were much lower than those for domestic coal combustion, which were determined to be $2.43-5.36 \mathrm{~g} \mathrm{~kg}^{-1}$ for raw bituminous coal (Du et al., 2016). 


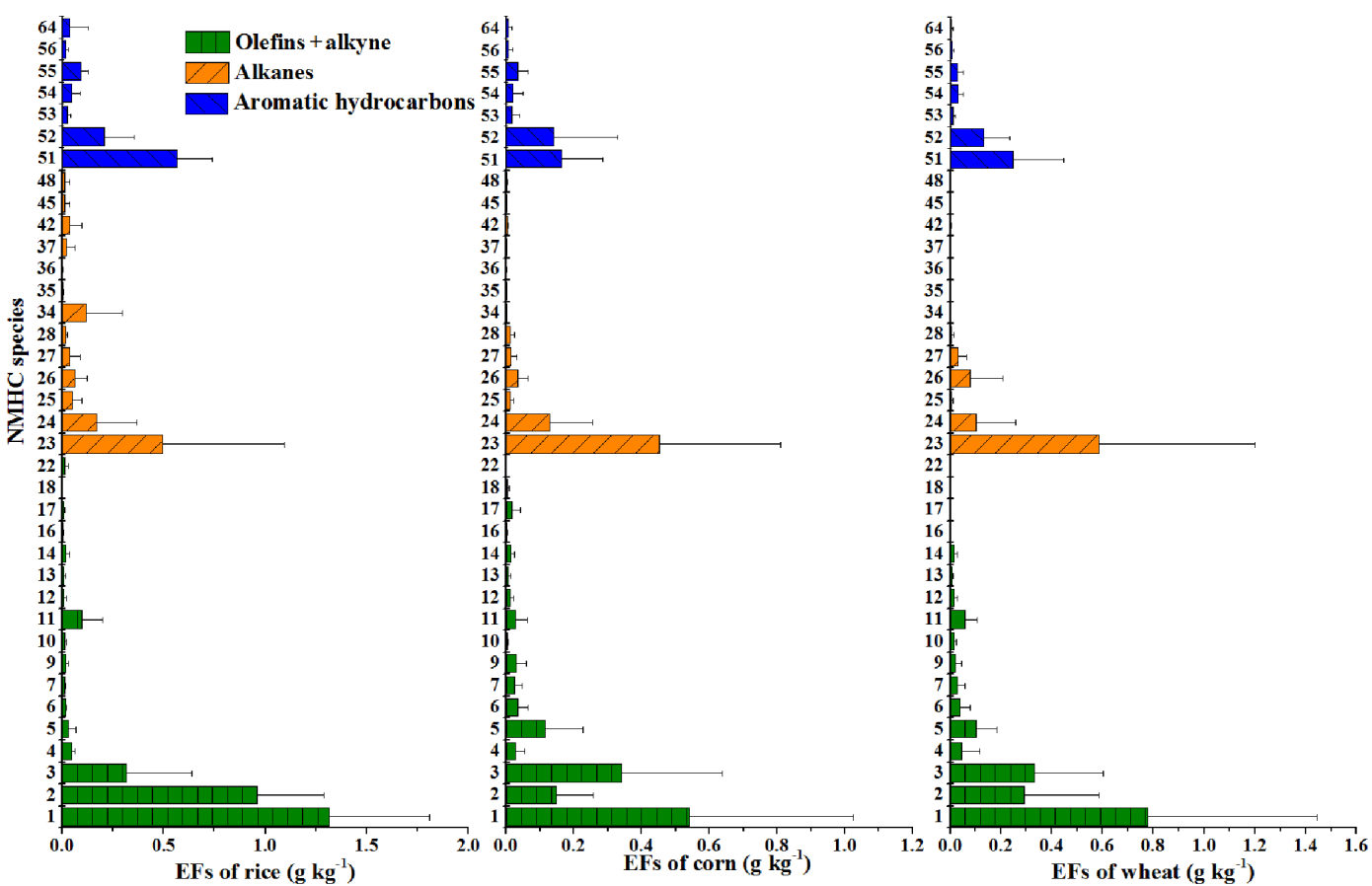

Figure 2. Emission factors (EFs) of NMHCs for straw burning of rice, corn and wheat. Only species with emission factors $>0.01 \mathrm{~g} \mathrm{~kg}^{-1} \mathrm{are}^{-}$ shown. The order of NMHC species is the same as Table S1, in which a comprehensive dataset of emission factors measured in this work is included.

Emission factors of the total speciated NMHCs analyzed by the GC-MSD/FID system were $5.04 \pm 2.04,2.47 \pm 2.11$ and $3.08 \pm 2.43 \mathrm{~g} \mathrm{~kg}^{-1}$ for rice, corn and wheat straw, respectively (Table 1). Our results were higher than those reported by previous studies (Li et al., 2009; Wang et al., 2014), partly due to the fact that more NMHCs were analyzed in our study (67 species in total). As shown in Fig. 1a-c, olefins and acetylene accounted for $56-58 \%$ of the total speciated NMHCs, followed by alkanes (22-28\%) and aromatic hydrocarbons (16-21\%). Table S1 and Fig. 2 show the emission factors of each NMHC for open burning of different straws. Emission factors of unsaturated hydrocarbons ranged from 1.37 (corn) to $2.91 \mathrm{~g} \mathrm{~kg}^{-1}$ (rice), with the majority being ethene, acetylene and propene. Emission factors of alkanes ranged from 0.69 (corn) to $1.09 \mathrm{~g} \mathrm{~kg}^{-1}$ (rice), with ethane and propane being the two most abundant compounds. The emission factors of aromatic hydrocarbons were in the range of 0.42 (corn) to 1.04 (rice), and benzene and toluene are dominant species. It is worth noting that major compounds in the three groups (alkanes, alkenes and aromatic hydrocarbons) were all negatively correlated with the modified combustion efficiency (Fig. S2), suggesting that more efficient combustion would reduce their emissions.

Based on their emission factors, we calculated the ozone formation potential for each NMHC. The summed ozone formation potentials were $22.5 \pm 10.1,13.7 \pm 12.4$ and $16.3 \pm 13.5 \mathrm{~g} \mathrm{~kg}^{-1}$ for open burning of rice, corn and wheat straw, respectively. As shown in Fig. 1d-e, the relative contri- butions of olefins to the total ozone formation potential could reach $>80 \%$. Ethene was the largest ozone precursor (35$42 \%$ ), followed by propene (16-28\%), and these two compounds contributed 58-64\% of the total ozone formation potential. Although the emission factors of aromatic hydrocarbons were lower than those of alkanes, their ozone formation potential was dominant over those of alkanes, with toluene being the largest contributor among all the aromatic hydrocarbons. The contribution of alkanes to the total ozone formation potential was minor (2-3\%). It is noted that oxygencontaining organic vapors in agricultural residue burning plumes could also have large ozone formation potentials. For example, the OFPs of formaldehyde and acetaldehyde for all experiments were $0.57-2.46$ times those of the 67 speciated NMHCs.

\subsection{Emission of particulate matter}

The emission factors of particulate matter were $3.73 \pm 3.28$, $5.44 \pm 3.43$ and $6.36 \pm 2.98 \mathrm{~g} \mathrm{~kg}^{-1}$ for rice, corn and wheat straw, lower than those reported in the previous studies (Table 1). As suggested by Robinson et al. (2007), the POA emission factors would decrease with increasing dilution ratios, due to evaporation of semi-volatile organic compounds. In this study, the dilution ratios ranged from 1300 to 4000, which were within the typical range of ambient dilution ratios (1000-10 000) (Robinson et al., 2007). Therefore, it can be expected that emission factors of primary organic car- 
bon (POC) measured in our study $\left(2.05-4.11 \mathrm{gC} \mathrm{kg}^{-1}\right)$ were lower than those measured by previous work with dilution ratios of 5-20 (Li et al., 2007; Ni et al., 2015). Moreover, it has been shown that the modified combustion efficiency could affect emission factors (Heringa et al., 2011; Stockwell et al., 2015). Figure S3 shows negative correlations of the modified combustion efficiency with emission factors of PM and POC ( $p<0.05$ for both cases), indicating that enhancement of combustion efficiency could reduce the emissions of PM and POC. In our study, all straws were pre-baked to reduce the moisture content to $<1 \%$, and this treatment could increase the modified combustion efficiency and thus reduce emission factors of particulate matters (Ni et al., 2015). In addition, the amount of straw burned each time in our experiments was much less than that in the fields, which is expected to avoid oxygen deficit during burning to some extent and thus increase the modified combustion efficiency as well.

While POA emission factors showed large variability for different types of straw, $\mathrm{BC}$ emission factors were relatively constant $\left(0.22-0.27 \mathrm{gC} \mathrm{kg}^{-1}\right)$. Since $\mathrm{BC}$ is a mixture of non-volatile compounds in particulate matters, as expected, its emission factors measured in our work were comparable to those reported under lower dilution conditions ( $\mathrm{Li}$ et al., 2007; $\mathrm{Ni}$ et al., 2015). The $\Delta[\mathrm{POA}] / \Delta[\mathrm{CO}]$ ratios ranged from 0.022 to 0.133 in our study, larger than those (0.001-0.067) measured in chamber studies for hard- and soft-wood fires (Grieshop et al., 2009b) and vegetation commonly burned in North American wildfires (Heringa et al., 2011), but lower than those (0.051-0.329) obtained in field campaigns (Jolleys et al., 2012).

For particle numbers, the emission factors were $(2.94 \pm 0.91) \times 10^{15}, \quad(7.29 \pm 4.17) \times 10^{15}, \quad$ and $(5.87 \pm 2.89) \times 10^{15}{\text { particle } \mathrm{kg}^{-1}}^{-1}$ for rice, corn, and wheat straw, respectively (Table 1 ). Our results were comparable to that $\left(1 \times 10^{15}\right.$ particle $\left.\mathrm{kg}^{-1}\right)$ for crop residue burning (Andreae and Merlet, 2001) and those $\left(3.2 \times 10^{15}\right.$ $10.9 \times 10^{15}$ particle $\mathrm{kg}^{-1}$ ) for wood burning (Hosseini et al., 2013), but 2 magnitudes larger than those for crop residue burning in a sealed stove (Zhang et al., 2008).

\subsection{Evolution of particles}

\subsubsection{Growth of particle size}

Figure 3 shows the evolution of particle size distribution after photochemical aging of $0,0.5,2.5$ and $5 \mathrm{~h}$. Aerosol particles emitted from open straw burning peaked at $50-90 \mathrm{~nm}$ under ambient dilution conditions. The geometric mean diameters for primarily emitted particles in this study were smaller than those (100-150 nm) reported for crop residual burning under low dilution conditions (H. Zhang et al., 2011; Li et al., 2015), probably due to evaporation of organic vapors under the high dilution conditions (Lipsky et al., 2006) and coagulation of fine particles under the low dilution conditions (Hossain et al., 2012).
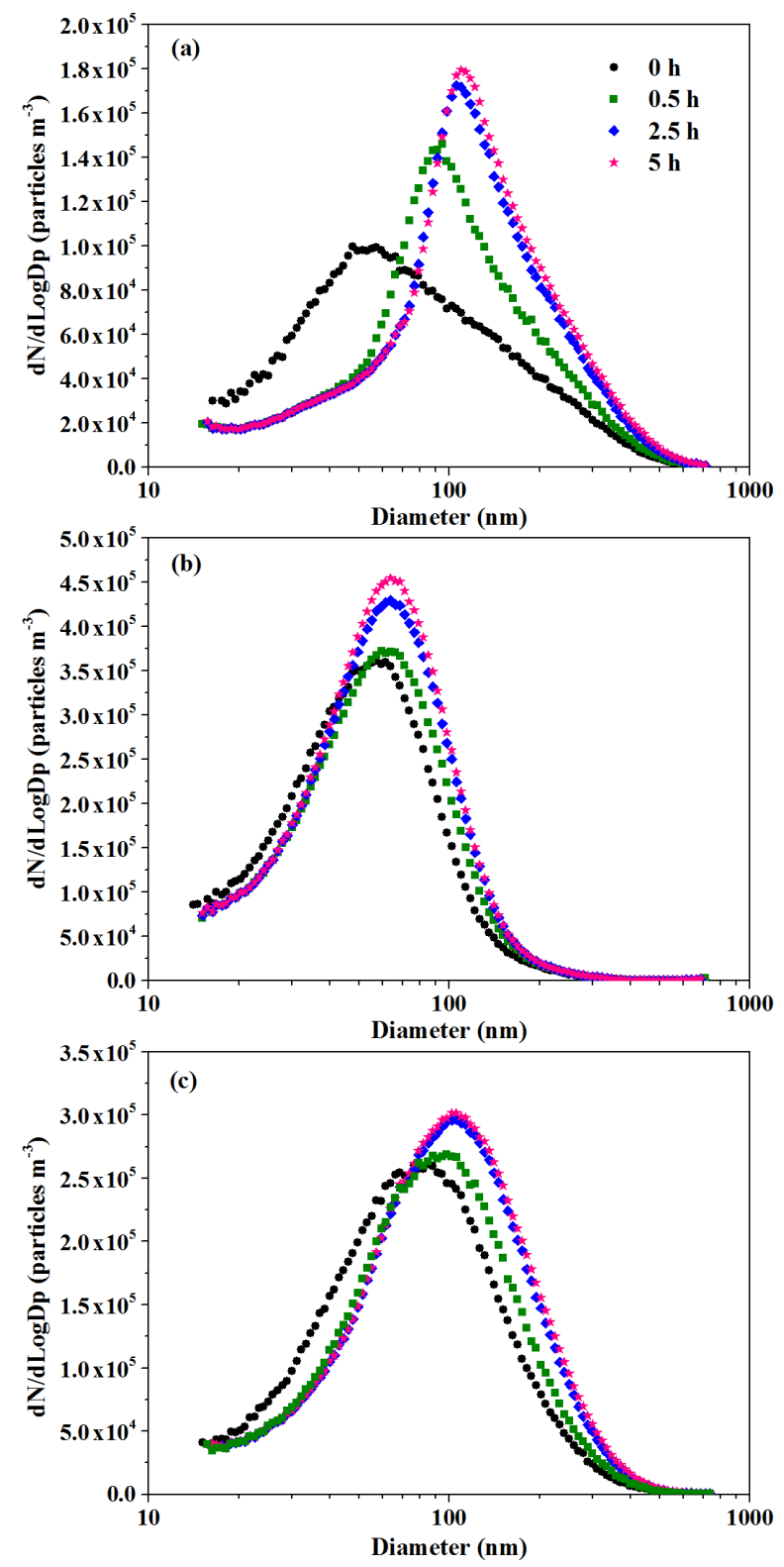

Figure 3. Particle size distributions in different burnings. (a) Burn 2: rice straw; (b) Burn 3: corn straw; (c) Burn 5: wheat straw.

After switching on black lamps, apparent growth of particle size was observed. In all the aging experiments, growth rates of particle diameters in the first $0.5 \mathrm{~h}$ were 10 times larger than those afterwards, and after $5 \mathrm{~h}$ aging the geometric mean diameters peaked at $60-120 \mathrm{~nm}$. For instance, in the photochemical aging experiment for wheat straw burning (Fig. 3c), the growth rate of particles was $18 \mathrm{~nm} \mathrm{~h}^{-1}$ in the first $0.5 \mathrm{~h}$ and decreased to $\sim 1 \mathrm{~nm} \mathrm{~h}^{-1}$ during the following $4.5 \mathrm{~h}$. The size distribution of aged aerosol particles in our study is similar to those of ambient particles under the 

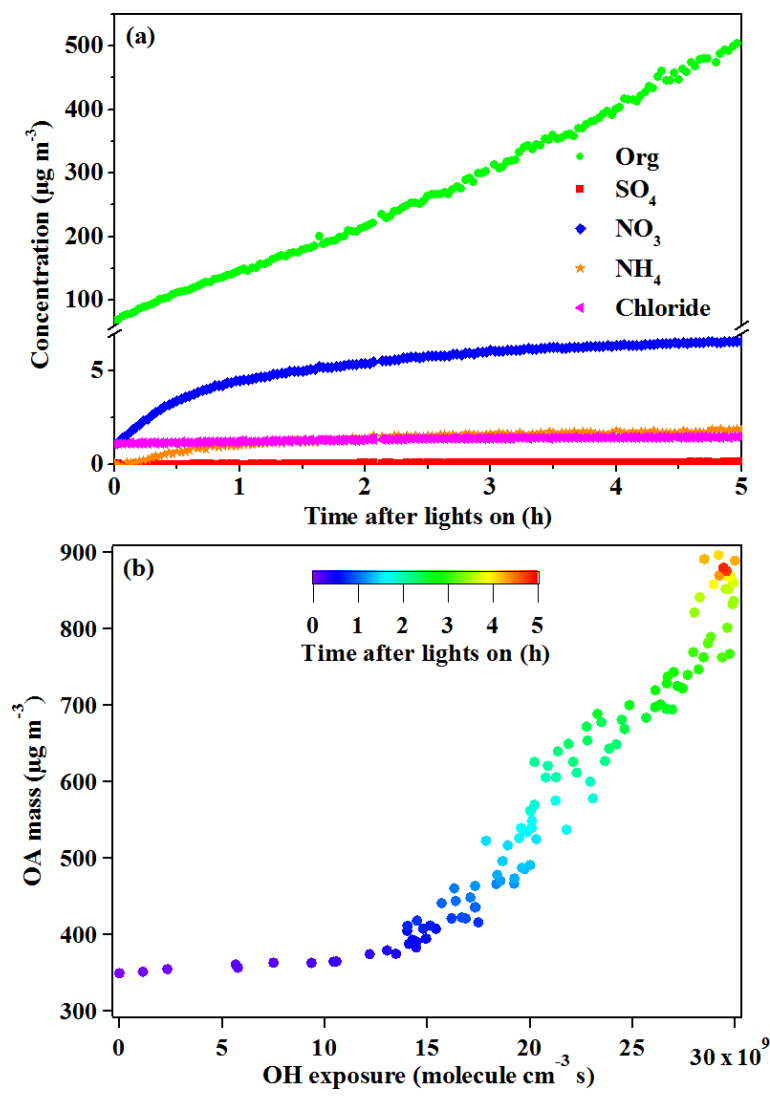

Figure 4. (a) The evolution of particulate matter components (Burn 2). (b) OA mass growth as a function of $\mathrm{OH}$ exposure (Burn 5).

severe biomass burning impact during haze events (Betha et al., 2014; Niu et al., 2016).

\subsubsection{Particle mass enhancement}

Figure 4 shows the chemical evolution of aerosol particles during the $5 \mathrm{~h}$ photochemical aging of wheat straw burning. During the whole process, OA kept increasing and was dominant over inorganic species. After $3 \mathrm{~h}$ of photochemical aging, the levels of all the inorganic species were constant, and nitrate was the second most abundant component, with a mass fraction of $7 \%$, followed by chloride ( $2 \%)$, ammonium $(1 \%)$ and sulfate $(<1 \%)$. Figure $4 \mathrm{~b}$ depicts $[\mathrm{OA}]$ evolution as a function of $\mathrm{OH}$ exposure. $\mathrm{OA}$ increased slowly in the first $\sim 0.2 \mathrm{~h}$, and then increased rapidly with $\mathrm{OH}$ exposure.

The OA enhancement ratio, defined as the mass ratio of aged $\mathrm{OA}$ at the end of each aging experiment to POA, was calculated. In the six aging experiments, the $\mathrm{OH}$ exposure and $\mathrm{OA}$ enhancement ratios ranged from $(1.87-4.97) \times 10^{10}$ molecule $\mathrm{cm}^{-3} \mathrm{~s}$ to $2.4-7.6$, respectively. Assuming an average $\mathrm{OH}$ concentration of $1.5 \times 10^{6}$ molecule $\mathrm{cm}^{-3}$ in the ambient air (Hayes et al., 2013), this means that rapid SOA formation would occur in 3.5-9.2 $\mathrm{h}$ during the daytime after straw burning. The OA enhancement ratios determined in our study were higher than those $(0.7-2.9)$ for the combustion of vegetation commonly burned in North American wildfires (Hennigan et al., 2011), and comparable to those (0.7-6.9) for wood burning (Grieshop et al., 2009b; Heringa et al., 2011).

Recently, Bruns et al. (2016) found that 22 NMOGs emitted from residential wood burning could explain the majority of the formed SOA. In our study, 20 of the 22 NMOGs were detected and quantified with the PTR-TOF-MS. Concentration differences of each compound before and after photo-oxidation were calculated to estimate the SOA formed from these precursors. Since SOA formation highly depends on oxidation conditions, SOA yields for a certain precursor vary with $\mathrm{VOC} / \mathrm{NO}_{x}$ ratios. In our work, we chose a set of SOA yields for these NMOGs based on the observed $\mathrm{VOC} / \mathrm{NO}_{x}$ ratio in the chamber experiments. More specifically, if the observed $\mathrm{VOC} / \mathrm{NO}_{x}$ ratio for a certain precursor in the chamber was within the $\mathrm{VOC} / \mathrm{NO}_{x}$ range reported in the literature, the mean value of the highest and lowest yields within the $\mathrm{VOC} / \mathrm{NO}_{x}$ range in the literature was used to estimate the SOA formed from the precursor in the chamber; if the observed $\mathrm{VOC} / \mathrm{NO}_{x}$ ratio for a certain precursor was higher than the maximum $\mathrm{VOC} / \mathrm{NO}_{x}$ ratio reported in the literature, we chose the yield reported at the maximum $\mathrm{VOC} / \mathrm{NO}_{x}$ ratio; if the observed $\mathrm{VOC} / \mathrm{NO}_{x}$ ratio was lower than the minimum $\mathrm{VOC} / \mathrm{NO}_{x}$ ratio reported in the literature, we chose the yield reported at the minimum $\mathrm{VOC} / \mathrm{NO}_{x}$ ratio.

Figure 5a shows the time series of POA, $\mathrm{SOA}_{\text {predicted }}$ and unexplained $\mathrm{SOA}$ in a typical aging experiment. The contribution of $\mathrm{SOA}_{\text {predicted }}$ by the 20 NMOGs was minor, and large fractions of observed SOA could not be explained. In all the experiments, only $5.0-27.3 \%$ of the observed SOA mass could be explained by the 20 NMOGs (Fig. 5b). Even if the highest SOA yield for each precursor reported in the literature were used, $60-90 \%$ of the observed SOA mass could still not be explained. It has been suggested that aqueousphase oxidation of alkenes could produce substantial SOA (Ervens et al., 2011). Considering large emissions of olefins from straw burning (Fig. 1a-c), we also estimated the SOA formed from the three most abundant alkenes (ethene, acetylene, and propene) with their newly developed SOA yields (Ge et al., 2016, 2017; Jia and Xu, 2016), and their total contribution to the observed SOA was found to be negligible $(<0.5 \%)$. It is noted that although over 80 VOCs species were quantified by the GC-MSD/FID and the PTR-TOF-MS in this study, only 20 species among them were taken into the SOA prediction because of the lack of published data for SOA yields. The unaccounted VOC species might be a reason for the discrepancy. On the other hand, as indicated by Deng et al. (2017), SOA yields obtained from chamber studies in purified air matrix might be lower than that in a real ambient air matrix. Consequently, using SOA yields from studies in a purified air matrix might also underpredict 

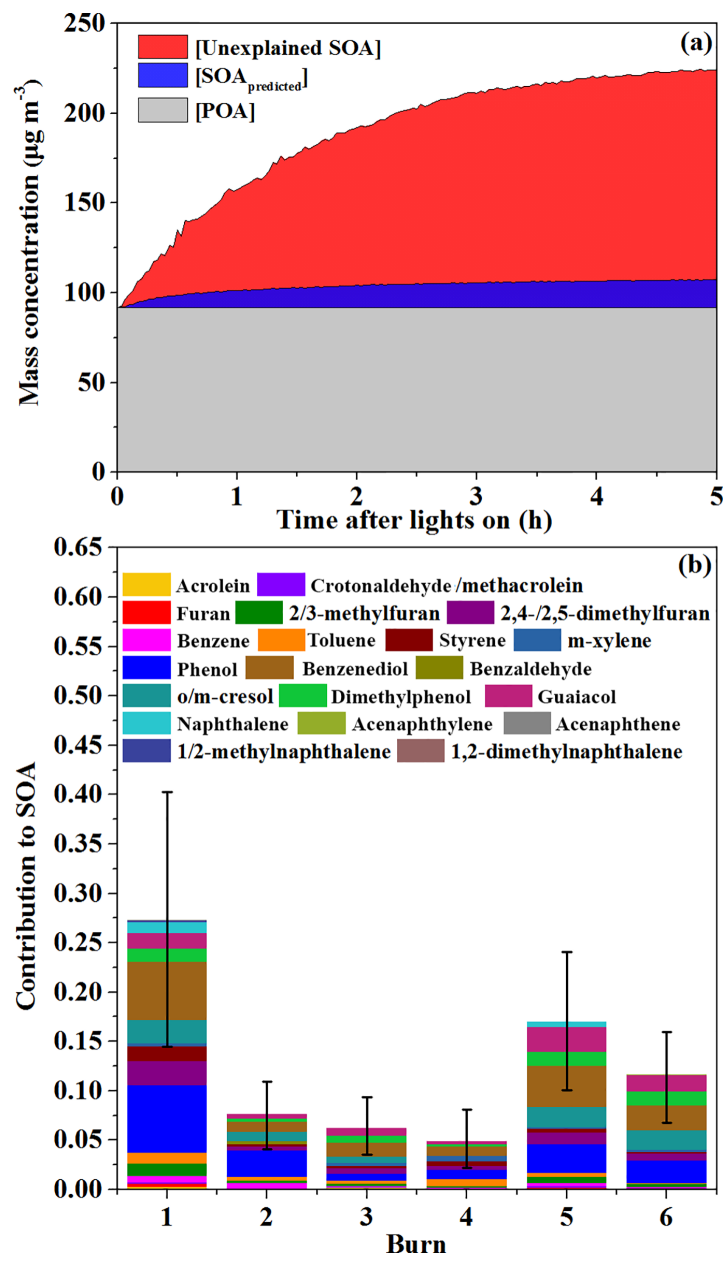

Figure 5. (a) Time series plots of concentrations of POA, secondary organic aerosol that can be explained by the reacted precursors $\left(\mathrm{SOA}_{\text {predicted }}\right)$, the difference between the formed SOA and the predicted SOA (unexplained SOA) in Burn 6. (b) Contribution of 20 NMOGs to the formed SOA at the end of photoreactions. Error bars correspond to the range of contributions when the lowest/highest SOA yields in references were used for all precursors.

SOA yields in the complex biomass burning plume matrix. Moreover, oxidation of particulate organic matter (POM), like semi-volatile organic compounds (SVOCs) and intermediate volatility organic compounds (IVOCs), would also contribute substantially to SOA formation (Presto et al., 2009; Zhao et al., 2014), yet this is not accounted for in our prediction. Above all, there are still unknown precursors and/or physicochemical processes contributing the majority of SOA formed from open straw burning.

\subsubsection{OA mass spectrum evolution}

In the high-resolution W mode of AMS, ions generated from particles could be identified by their exact mass-charge ratio $(\mathrm{m} / \mathrm{z})$ and then grouped into the $\mathrm{CHON}, \mathrm{CHO}, \mathrm{CHN}$ and $\mathrm{CH}$ families. Figure 6 presents the evolution of OA mass spec-
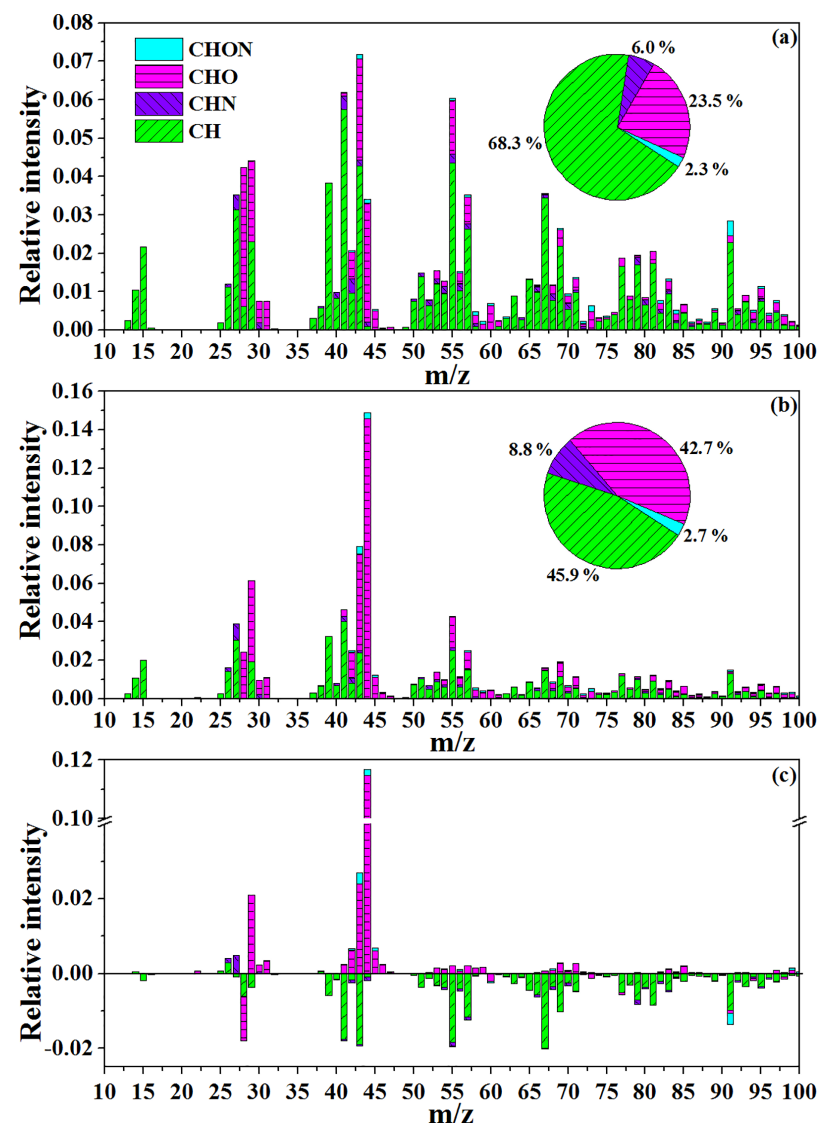

Figure 6. (a) Mass spectrum of POA; (b) mass spectrum of aged $\mathrm{OA}$; (c) difference in mass spectra between aged OA and POA. The data were all taken from Burn 5.

tra. For POA (Fig. 6a), the CH-family was the major component, with a mass fraction of $68 \%$, followed by $\mathrm{CHO}(23 \%)$, CHN (6\%), and CHON (2\%). The ions at $m / z 43,41$ and 55 were the dominant peaks in the POA mass spectrum. The major ions at $m / z 27,39,41,55,57,67$ and 69 belonged to the $\mathrm{CH}$-family and could be the fragments of hydrocarbons (Weimer et al., 2008). The peaks at $m / z 28,29,43,44$ and 55 contained considerable $\mathrm{CHO}$ ions, and the corresponding ions $\left(\mathrm{CO}^{+}, \mathrm{CHO}^{+}, \mathrm{C}_{2} \mathrm{H}_{3} \mathrm{O}^{+}, \mathrm{CO}_{2}^{+}\right.$and $\left.\mathrm{C}_{3} \mathrm{H}_{3} \mathrm{O}^{+}\right)$could be the fragments of aldehydes, ketones and carboxylic acid $(\mathrm{Ng}$ et al., 2011a). The peak at $m / z 91$ was mainly attributed to $\mathrm{C}_{7} \mathrm{H}_{7}^{+}$, possibly originating from aromatic compounds.

The mass spectra of aged OA were quite different from those of POA (Fig. 6b-c). The mass fraction of the $\mathrm{CH}$ family decreased to $46 \%$ and was comparable to that of the CHO-family, while the contribution of $\mathrm{N}$-containing OA (CHN and CHON) increased to $\sim 11 \%$. The ions at $m / z 44$ and 43 , mainly coming from the $\mathrm{CHO}$-family, became the dominant peaks for the aged OA. The fractions of two major masses at $m / z 44\left(f_{44}\right)$ and $m / z 43\left(f_{43}\right)$ in OA can be used to generate an $f_{44}$ vs. $f_{43}$ triangular space, in which oxygenated organic aerosol (OOA) moves towards the apex 

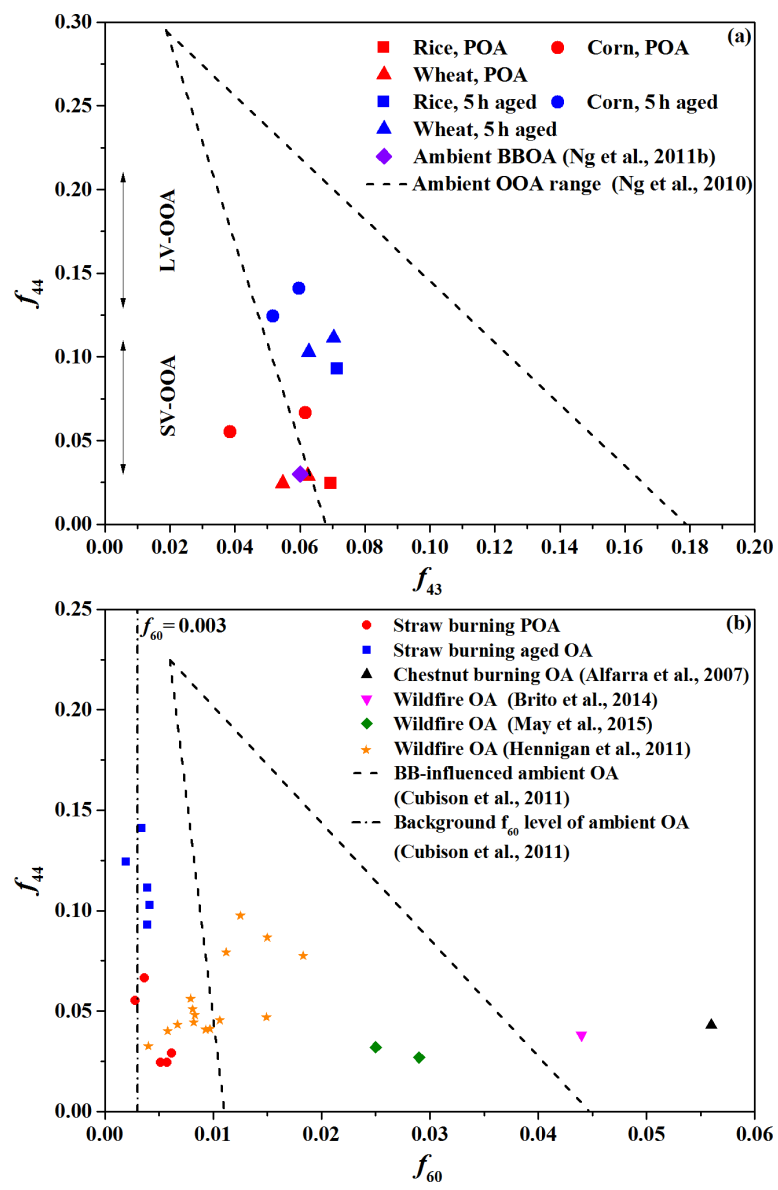

Figure 7. (a) Comparison of $f_{44}$ vs. $f_{43}$ determined in our work with those for the ambient BBOA data sets (Ng et al., 2011b) and the ambient OOA range ( $\mathrm{Ng}$ et al., 2010). The typical $f_{44}$ ranges of ambient SV-OOA and LV-OOA are indicated with the vertical arrows. (b) Comparison of $f_{44}$ vs. $f_{60}$ for straw burning OA with those for other types of biomass burning OA (Alfarra et al., 2007; Hennigan et al., 2011; Cubison et al., 2011; Brito et al., 2014; May et al., 2015).

during the aging process ( $\mathrm{Ng}$ et al., 2010). In addition, $f_{44}$ in the ambient air was suggested to be $0.07 \pm 0.04$ for semivolatile OOA (SV-OOA) and $0.17 \pm 0.04$ for low-volatility OOA (LV-OOA), respectively ( $\mathrm{Ng}$ et al., 2010). Figure 7a plots $f_{44}$ and $f_{43}$ of the POA and the aged OA in all six experiments. Most of the data are within the $f_{44}$ vs. $f_{43}$ triangular space and close to the left margin. Photochemical aging led to an increase in $f_{44}$ for all the experiments, suggesting transformation of OA from SV-OOA to LV-OOA. For comparison, the $f_{43}$ did not change significantly in all the experiments. The main ions at $m / z 43$ were $\mathrm{C}_{2} \mathrm{H}_{3} \mathrm{O}^{+}$and $\mathrm{C}_{3} \mathrm{H}_{7}^{+}$. It can be observed in Fig. $6 \mathrm{c}$ that the increased contribution of $\mathrm{C}_{2} \mathrm{H}_{3} \mathrm{O}^{+}$and the decreased contribution of $\mathrm{C}_{3} \mathrm{H}_{7}^{+}$were comparable during photoreaction.

The ion at $m / z 60$, mainly consisting of $\mathrm{C}_{2} \mathrm{H}_{4} \mathrm{O}_{2}^{+}$, is regarded as a BBOA marker, and the mass fraction of this ion in $\mathrm{OA}, f_{60}$, is widely used to probe the evolution of BBOA (Brito et al., 2014; May et al., 2015). Figure 7b plots the evolution of $f_{44}$ and $f_{60}$ in all the experiments conducted in this study, in order to compare them with measurements in aging biomass burning plumes (Cubison et al., 2011) and those in the POA from different types of biomass burning (Alfarra et al., 2007; Brito et al., 2014; May et al., 2015). Photooxidation caused an increase in $f_{44}$ and a decrease in $f_{60}$, and this is consistent with the general evolution of OA in ambient biomass burning plumes (Cubison et al., 2011). However, our measured $f_{60}, 0.003-0.006$ in the POA from open straw burning and 0.002-0004 in aged OA, were all lower than those from other field campaigns and quite near the background $f_{60}$ level of 0.003 for ambient OA (Cubison et al., 2011; Fig. 7b). Low values of $f_{60}(0.005-0.02)$ were also reported by Hennigan et al. (2011) in a chamber study for fuels commonly burned in wildfires. In their study, biomass burning took place in a $3000 \mathrm{~m}^{3}$ combustion chamber, and the smokes were then injected into another chamber for aging experiments with a dilution ratio of $\sim 25$. Previous studies have demonstrated that levoglucosan is a semi-volatile compound with a saturation concentration of $\sim 8 \mu \mathrm{g} \mathrm{m}^{-3}$ at $293 \mathrm{~K}$ (Grieshop et al., 2009b; Huffman et al., 2009; Hennigan et al., 2011). As a result, the high dilution conditions used in our study would cause levoglucosan to evaporate, and this may at least partly explain the low $f_{60}$ observed in the POA from straw burning. From previous studies, the levoglucosan / OC ratios of straw burning ranging from 4.92 to $16.8 \%$ (4 types of vegetation summarized; Dhammapala et al., 2007; Kim Oanh et al., 2011; Hall et al., 2012) were not significantly (two-sample $t$-test, $p>0.05$ ) lower than those of prescribed fuel burning, wildfire and wood burning ranging from 1.46 to $13.5 \%$ (20 types of vegetation summarized; Hosseini et al., 2013; Shahid et al., 2015). So the difference in fuel type cannot explain the lower $f_{60}$ observed in our study.

\subsubsection{Elemental ratio and oxidation state of $\mathrm{OA}$}

In this study, the $\mathrm{O} / \mathrm{C}$ and $\mathrm{H} / \mathrm{C}$ ratios in the POA from different straws burning were in the ranges of $0.20-0.38$ and $1.58-1.74$, respectively. After $5 \mathrm{~h}$ aging, $\mathrm{O} / \mathrm{C}$ increased and $\mathrm{H} / \mathrm{C}$ decreased (Table 2). Kroll et al. (2011) proposed a metric, the average carbon oxidation state $\left(\mathrm{OS}_{\mathrm{c}}\right)$, to describe the degree of oxidation of atmospheric organic species. $\mathrm{OS}_{\mathrm{c}}$ could be calculated from the elemental composition of OA measured by AMS, given by Eq. (7):

$\mathrm{OS}_{\mathrm{c}}=2 \times \mathrm{O} / \mathrm{C}-\mathrm{H} / \mathrm{C}$.

In this study, the $\mathrm{OS}_{\mathrm{c}}$ values for the fresh POA from open straw burning ranged from -1.25 to -0.89 , consistent with those suggested for BBOA ( -1 to -0.7 ) (Kroll et al., 2011). During photochemical aging, the $\mathrm{OS}_{\mathrm{c}}$ values increased linearly $(p<0.001)$ with $\mathrm{OH}$ exposure (Fig. 8), and the slopes were quite near each other even for different types of straws, 
Table 2. Overview of important experimental conditions and key results in the photochemical oxidation experiments. The unit for OH exposure is $10^{10}$ molecule $\mathrm{cm}^{-3} \mathrm{~s}$. NA: data were not available because no data were recorded in the $\mathrm{W}$-mode.

\begin{tabular}{|c|c|c|c|c|c|c|c|c|c|c|c|}
\hline \multirow[t]{2}{*}{ NO. } & \multirow[t]{2}{*}{ Straw type } & \multirow[t]{2}{*}{ Temp $\left({ }^{\circ} \mathrm{C}\right)$} & \multirow[t]{2}{*}{ RH (\%) } & \multirow{2}{*}{$\begin{array}{r}\mathrm{OH} \\
\text { exposure }\end{array}$} & \multicolumn{3}{|c|}{ POA } & \multicolumn{3}{|c|}{ Aged OA } & \multirow{2}{*}{$\begin{array}{l}\text { OA } \\
\text { ER }\end{array}$} \\
\hline & & & & & $\mathrm{O} / \mathrm{C}$ & $\mathrm{H} / \mathrm{C}$ & $\mathrm{OS}_{\mathrm{c}}$ & $\mathrm{O} / \mathrm{C}$ & $\mathrm{H} / \mathrm{C}$ & $\mathrm{OS}_{\mathrm{c}}$ & \\
\hline & & & & & NA & & NA & NA & NA & NA & 2.7 \\
\hline Burn & & & & 4. & 25 & 1.74 & -1.25 & 0.50 & 1.65 & -0.65 & 7.6 \\
\hline Burn 3 & Corn & $5.5 \pm 0.4$ & $53.0 \pm 2$ & 4.1 & 0.38 & 1.66 & & 0.60 & 1.66 & -0.46 & 3.6 \\
\hline Burn 4 & Corn & $26.1 \pm 0.4$ & $48.4 \pm 2.2$ & 4.16 & 0.30 & 1.58 & -0.97 & 0.65 & 1.57 & -0.26 & 4.6 \\
\hline Burn 5 & Wheat & & & 3.2 & 0.20 & 1.66 & -1.25 & 0.50 & 1.56 & -0.55 & 2.4 \\
\hline Burn 6 & Wheat & $25.2 \pm 0.4$ & $55.1 \pm 2.7$ & 1.87 & 0.26 & 1.71 & -1.20 & 0.53 & 1.66 & -0.61 & 6.6 \\
\hline
\end{tabular}

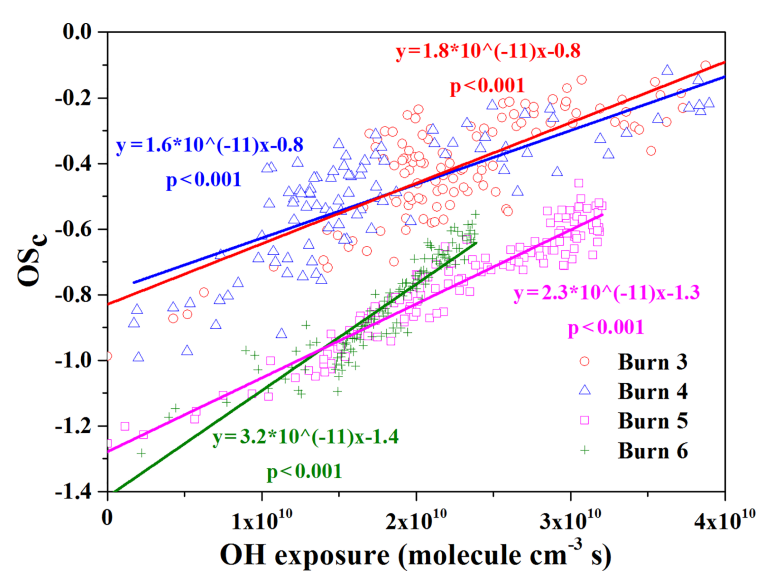

Figure 8. The growth of the $\mathrm{OA}$ carbon oxidation state with $\mathrm{OH}$ exposure for burning corn (Burns 3 and 4) and wheat (Burns 5 and 6) straws. Data for burning rice straws were not included since in Burn 1 AMS was then not run in $\mathrm{W}$-mode.

implying AMS measured $\mathrm{OS}_{\mathrm{c}}$ might be a good indicator of $\mathrm{OH}$ exposure and thereby of photochemical aging.

Figure 9 shows the Van Krevelen diagram of OA. In this study, the slopes of linear correlations between $\mathrm{H} / \mathrm{C}$ and $\mathrm{O} / \mathrm{C}$ range from -0.49 to -0.24 for the five experiments. Slopes of $-1,0.5$ and 0 in the Van Krevelen diagrams indicate addition of carboxylic acids without fragmentation, addition of carboxylic acids with fragmentation, and addition of alcohols/peroxides, respectively (Heald et al., 2010; $\mathrm{Ng}$ et al., 2011a). Therefore, the slopes determined in our study suggest that open straw burning OA aging resulted in net changes in chemical composition equivalent to addition of carboxylic acid groups with $\mathrm{C}-\mathrm{C}$ bond breakage and addition of alcohol/peroxide functional groups.

\section{Conclusion}

In this study, primary emissions of open burning of rice, corn and wheat straw and their photochemistry were investigated using a large indoor chamber. Emission factors of $\mathrm{NO}_{x}, \mathrm{NH}_{3}, \mathrm{SO}_{2}, 67 \mathrm{NMHCs}, \mathrm{PM}$ and particle number were

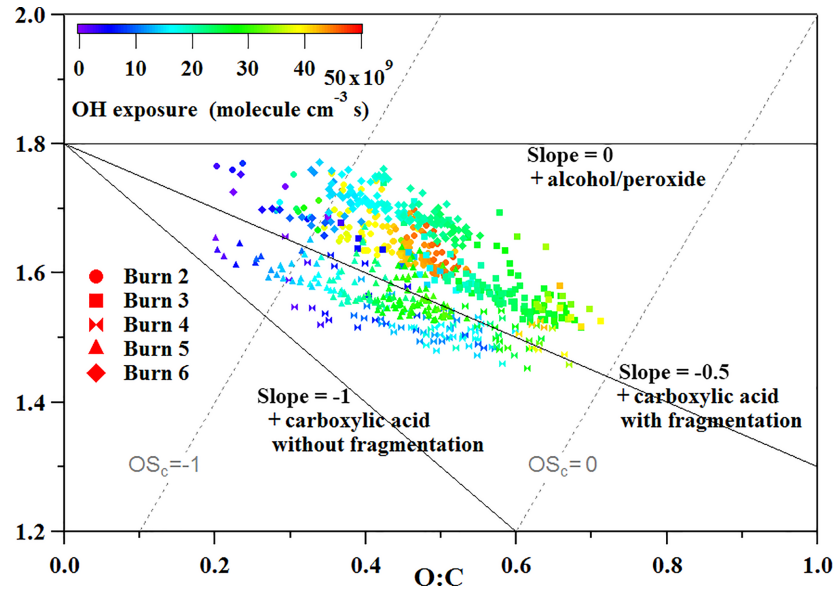

Figure 9. Van Krevelen diagram for the OA. Each slope corresponds to the addition of a specific functional group to an aliphatic carbon.

measured under dilution ratios ranging from 1300 to 4000 . Emission factors of PM (3.73-6.36 $\left.\mathrm{g} \mathrm{kg}^{-1}\right)$ and POC (2.05$4.11 \mathrm{gC} \mathrm{kg}^{-1}$ ) were lower than those reported in previous studies conducted at lower dilution ratios, probably due to the evaporation of semi-volatile organic compounds. Emission factors of POC, PM and major NMHC compounds were all negatively correlated with the modified combustion efficiency, suggesting that incomplete burning of agricultural residues could lead to larger primary emission.

Both agricultural residue burning and domestic coal combustion have been recognized as contributing substantially to the deteriorating regional air quality, especially in rural areas of China (Pan et al., 2015; J. Liu et al., 2016; Zhu et al., 2016). The emission factors of the speciated NMHCs, PM, $\mathrm{NO}_{x}, \mathrm{CO}$ and $\mathrm{SO}_{2}$ from combustion of raw bituminous coal, which is currently prevalent for cooking and heating in rural areas, have been reported to be $0.56-5.40,25.49 \pm 2.30$, $0.97 \pm 0.03,208 \pm 5$ and $2.43-5.36 \mathrm{~g} \mathrm{~kg}^{-1}$, respectively (Du et al., 2016; Li et al., 2016; Liu et al., 2017). Annually burned crop residues and domestic coals were estimated to be $160 \mathrm{Tg}$ (Q. Li et al., 2016) and 99.6 Tg (NBSPRC, 2014) in China. Therefore, with the emission factors of the speciated 
NMHCs $\left(2.47-5.04 \mathrm{~g} \mathrm{~kg}^{-1}\right), \mathrm{PM}\left(3.73-6.36 \mathrm{~g} \mathrm{~kg}^{-1}\right), \mathrm{NO}_{x}$ $\left(1.47-5.00 \mathrm{~g} \mathrm{~kg}^{-1}\right), \mathrm{CO}\left(46.1-63.5 \mathrm{~g} \mathrm{~kg}^{-1}\right)$ and $\mathrm{SO}_{2}(0.07-$ $0.99 \mathrm{~g} \mathrm{~kg}^{-1}$ ) measured for agricultural residue burning in this study, agricultural residue burning might emit more NMHCs and $\mathrm{NO}_{x}$ but less primary $\mathrm{PM}, \mathrm{CO}$ and $\mathrm{SO}_{2}$ than domestic coal burning on a national scale.

Photochemical aging of primary emissions was investigated with $\mathrm{OH}$ exposure equal to 3.2-9.2 h under typical ambient conditions, and at the end of experiments the OA mass concentrations increased by a factor of 2.4-7.6, suggesting that SOA could be rapidly produced within several hours. Our estimation suggests that phenols are the most important identified SOA precursors, and more than $70 \%$ of the formed OA still cannot be explained by the oxidation of known precursors. Measurements using HR-TOF-AMS reveal that after photochemical aging, signals for oxygen- and nitrogencontaining compounds were largely increased, with $\mathrm{OS}_{\mathrm{c}}$ increased in a highly significant linear way with $\mathrm{OH}$ exposure.

Data availability. The data used in this publication are available to the community and can be accessed by request to the corresponding author.

\section{The Supplement related to this article is available online at https://doi.org/10.5194/acp-17-14821-2017- supplement.}

Competing interests. The authors declare that they have no conflict of interest.

Acknowledgements. This study was supported by the Strategic Priority Research Program of the Chinese Academy of Sciences (grant no. XDB05010200), the National Natural Science Foundation of China (grant no. 41530641/41571130031/41673116/41503105), the National Key Research and Development Program (2016YFC0202204) and the Guangzhou Science Technology and Innovation Commission (201505231532347).

Edited by: Aijun Ding

Reviewed by: two anonymous referees

\section{References}

Adler, G., Flores, J. M., Abo Riziq, A., Borrmann, S., and Rudich, Y.: Chemical, physical, and optical evolution of biomass burning aerosols: a case study, Atmos. Chem. Phys., 11, 1491-1503, https://doi.org/10.5194/acp-11-1491-2011, 2011.

Aiken, A. C., DeCarlo, P. F., and Jimenez, J. L.: Elemental analysis of organic species with electron ionization highresolution mass spectrometry, Anal. Chem., 79, 8350-8358, https://doi.org/10.1021/ac071150w, 2007.
Aiken, A. C., Decarlo, P. F., Kroll, J. H., Worsnop, D. R., Huffman, J. A., Docherty, K. S., Ulbrich, I. M., Mohr, C., Kimmel, J. R., Sueper, D., Sun, Y., Zhang, Q., Trimborn, A., Northway, M., Ziemann, P. J., Canagaratna, M. R., Onasch, T. B., Alfarra, M. R., Prevot, A. S. H., Dommen, J., Duplissy, J., Metzger, A., Baltensperger, U., and Jimenez, J. L.: $\mathrm{O} / \mathrm{C}$ and $\mathrm{OM} / \mathrm{OC}$ ratios of primary, secondary, and ambient organic aerosols with high-resolution time-of-flight aerosol mass spectrometry, Environ. Sci. Technol., 42, 4478-4485, https://doi.org/10.1021/es703009q, 2008.

Akagi, S. K., Yokelson, R. J., Wiedinmyer, C., Alvarado, M. J., Reid, J. S., Karl, T., Crounse, J. D., and Wennberg, P. O.: Emission factors for open and domestic biomass burning for use in atmospheric models, Atmos. Chem. Phys., 11, 4039-4072, https://doi.org/10.5194/acp-11-4039-2011, 2011.

Alfarra, M. R., Prevot, A. S. H., Szidat, S., Sandradewi, J., Weimer, S., Lanz, V. A., Schreiber, D., Mohr, M., and Baltensperger, U.: Identification of the mass spectral signature of organic aerosols from wood burning emissions, Environ. Sci. Technol., 41, 57705777, https://doi.org/10.1021/es062289b, 2007.

Alves, N. d. O., Brito, J., Caumo, S., Arana, A., Hacon, S. d. S., Artaxo, P., Hillamo, R., Teinila, K., Batistuzzo de Medeiros, S. R., and Vasconcellos, P. d. C.: Biomass burning in the Amazon region: Aerosol source apportionment and associated health risk assessment, Atmos. Environ., 120, 277-285, https://doi.org/10.1016/j.atmosenv.2015.08.059, 2015.

Andreae, M. O. and Merlet, P.: Emission of trace gases and aerosols from biomass burning, Global Biogeochem. Сy., 15, 955-966, https://doi.org/10.1029/2000GB001382, 2001.

Andreae, M. O., Rosenfeld, D., Artaxo, P., Costa, A. A., Frank, G. P., Longo, K. M., and Silva-Dias, M. A. F.: Smoking Rain Clouds over the Amazon, Science, 303, 1337-1342, https://doi.org/10.1126/science.1092779, 2004.

Arnold, S. R., Emmons, L. K., Monks, S. A., Law, K. S., Ridley, D. A., Turquety, S., Tilmes, S., Thomas, J. L., Bouarar, I., Flemming, J., Huijnen, V., Mao, J., Duncan, B. N., Steenrod, S., Yoshida, Y., Langner, J., and Long, Y.: Biomass burning influence on high-latitude tropospheric ozone and reactive nitrogen in summer 2008: a multi-model analysis based on POLMIP simulations, Atmos. Chem. Phys., 15, 6047-6068, https://doi.org/10.5194/acp-15-6047-2015, 2015.

Betha, R., Zhang, Z., and Balasubramanian, R.: Influence of trans-boundary biomass burning impacted air masses on submicron particle number concentrations and size distributions, Atmos. Environ., 92, 9-18, https://doi.org/10.1016/j.atmosenv.2014.04.002, 2014.

Bond, T. C., Streets, D. G., Yarber, K. F., Nelson, S. M., Woo, J. H., and Klimont, Z.: A technology-based global inventory of black and organic carbon emissions from combustion, J. Geophys. Res.-Atmos., 109, D14203, https://doi.org/10.1029/2003jd003697, 2004.

Bond, T. C., Doherty, S. J., Fahey, D. W., Forster, P. M., Berntsen, T., DeAngelo, B. J., Flanner, M. G., Ghan, S., Kaercher, B., Koch, D., Kinne, S., Kondo, Y., Quinn, P. K., Sarofim, M. C., Schultz, M. G., Schulz, M., Venkataraman, C., Zhang, H., Zhang, S., Bellouin, N., Guttikunda, S. K., Hopke, P. K., Jacobson, M. Z., Kaiser, J. W., Klimont, Z., Lohmann, U., Schwarz, J. P., Shindell, D., Storelvmo, T., Warren, S. G., and Zender, C. S.: Bounding the role of black carbon in the climate system: A sci- 
entific assessment, J. Geophys. Res.-Atmos., 118, 5380-5552, https://doi.org/10.1002/jgrd.50171, 2013.

Borras, E. and Tortajada-Genaro, L. A.: Secondary organic aerosol formation from the photo-oxidation of benzene, Atmos. Environ., 47, 154-163, https://doi.org/10.1016/j.atmosenv.2011.11.020, 2012.

Brassard, P., Palacios, J. H., Godbout, S., Bussieres, D., Lagace, R., Larouche, J. P., and Pelletier, F.: Comparison of the gaseous and particulate matter emissions from the combustion of agricultural and forest biomasses, Bioresour. Technol., 155, 300-306, https://doi.org/10.1016/j.biortech.2013.12.027, 2014.

Brito, J., Rizzo, L. V., Morgan, W. T., Coe, H., Johnson, B., Haywood, J., Longo, K., Freitas, S., Andreae, M. O., and Artaxo, P.: Ground-based aerosol characterization during the South American Biomass Burning Analysis (SAMBBA) field experiment, Atmos. Chem. Phys., 14, 12069-12083, https://doi.org/10.5194/acp-14-12069-2014, 2014.

Bruns, E. A., El Haddad, I., Slowik, J. G., Kilic, D., Klein, F., Baltensperger, U., and Prevot, A. S. H.: Identification of significant precursor gases of secondary organic aerosols from residential wood combustion, Sci. Rep., 6, 27881, https://doi.org/10.1038/srep27881, 2016.

Bruns, E. A., Slowik, J. G., El Haddad, I., Kilic, D., Klein, F., Dommen, J., Temime-Roussel, B., Marchand, N., Baltensperger, U., and Prévôt, A. S. H.: Characterization of gas-phase organics using proton transfer reaction time-of-flight mass spectrometry: fresh and aged residential wood combustion emissions, Atmos. Chem. Phys., 17, 705-720, https://doi.org/10.5194/acp-17-7052017, 2017.

Canagaratna, M. R., Jimenez, J. L., Kroll, J. H., Chen, Q., Kessler, S. H., Massoli, P., Hildebrandt Ruiz, L., Fortner, E., Williams, L. R., Wilson, K. R., Surratt, J. D., Donahue, N. M., Jayne, J. T., and Worsnop, D. R.: Elemental ratio measurements of organic compounds using aerosol mass spectrometry: characterization, improved calibration, and implications, Atmos. Chem. Phys., 15, 253-272, https://doi.org/10.5194/acp-15-253-2015, 2015.

Cao, G., Zhang, X., Gong, S., and Zheng, F.: Investigation on emission factors of particulate matter and gaseous pollutants from crop residue burning, J. Environ. Sci., 20, 50-55, https://doi.org/10.1016/S1001-0742(08)60007-8, 2008.

Carter, W. P. L.: Reactivity estimates for selected consumer product compounds, Air resources Board, California, Contract No. 06408, 72-99, 2008.

Chan, A. W. H., Kautzman, K. E., Chhabra, P. S., Surratt, J. D., Chan, M. N., Crounse, J. D., Kürten, A., Wennberg, P. O., Flagan, R. C., and Seinfeld, J. H.: Secondary organic aerosol formation from photooxidation of naphthalene and alkylnaphthalenes: implications for oxidation of intermediate volatility organic compounds (IVOCs), Atmos. Chem. Phys., 9, 3049-3060, https://doi.org/10.5194/acp-9-3049-2009, 2009.

Chan, A. W. H., Chan, M. N., Surratt, J. D., Chhabra, P. S., Loza, C. L., Crounse, J. D., Yee, L. D., Flagan, R. C., Wennberg, P. O., and Seinfeld, J. H.: Role of aldehyde chemistry and $\mathrm{NO}_{x}$ concentrations in secondary organic aerosol formation, Atmos. Chem. Phys., 10, 7169-7188, https://doi.org/10.5194/acp10-7169-2010, 2010.

Cheng, Y., Engling, G., He, K.-B., Duan, F.-K., Ma, Y.-L., Du, Z.Y., Liu, J.-M., Zheng, M., and Weber, R. J.: Biomass burning contribution to Beijing aerosol, Atmos. Chem. Phys., 13, 77657781, https://doi.org/10.5194/acp-13-7765-2013, 2013.

Cheng, Y., Engling, G., Moosmaller, H., Arnott, W. P., Chen, L. W. A., Wold, C. E., Hao, W. M., and He, K. B.: Light absorption by biomass burning source emissions, Atmos. Environ., 127, 347354, https://doi.org/10.1016/j.atmosenv.2015.12.045, 2016.

Chhabra, P. S., Ng, N. L., Canagaratna, M. R., Corrigan, A. L., Russell, L. M., Worsnop, D. R., Flagan, R. C., and Seinfeld, J. H.: Elemental composition and oxidation of chamber organic aerosol, Atmos. Chem. Phys., 11, 8827-8845, https://doi.org/10.5194/acp-11-8827-2011, 2011.

Christian, T. J., Yokelson, R. J., Cárdenas, B., Molina, L. T., Engling, G., and Hsu, S.-C.: Trace gas and particle emissions from domestic and industrial biofuel use and garbage burning in central Mexico, Atmos. Chem. Phys., 10, 565-584, https://doi.org/10.5194/acp-10-565-2010, 2010.

Cubison, M. J., Ortega, A. M., Hayes, P. L., Farmer, D. K., Day, D., Lechner, M. J., Brune, W. H., Apel, E., Diskin, G. S., Fisher, J. A., Fuelberg, H. E., Hecobian, A., Knapp, D. J., Mikoviny, T., Riemer, D., Sachse, G. W., Sessions, W., Weber, R. J., Weinheimer, A. J., Wisthaler, A., and Jimenez, J. L.: Effects of aging on organic aerosol from open biomass burning smoke in aircraft and laboratory studies, Atmos. Chem. Phys., 11, 12049-12064, https://doi.org/10.5194/acp-11-12049-2011, 2011.

DeCarlo, P. F., Slowik, J. G., Worsnop, D. R., Davidovits, P., and Jimenez, J. L.: Particle morphology and density characterization by combined mobility and aerodynamic diameter measurements. Part 1: Theory, Aerosol Sci. Tech., 38, 1185-1205, https://doi.org/10.1080/027868290903907, 2004.

DeCarlo, P. F., Kimmel, J. R., Trimborn, A., Northway, M. J., Jayne, J. T., Aiken, A. C., Gonin, M., Fuhrer, K., Horvath, T., Docherty, K. S., Worsnop, D. R., and Jimenez, J. L.: Field-deployable, high-resolution, time-of-flight aerosol mass spectrometer, Anal. Chem., 78, 8281-8289, https://doi.org/10.1021/ac061249n, 2006.

Deng, W., Liu, T., Zhang, Y., Situ, S., Hu, Q., He, Q., Zhang, Z., Lü, S., Bi, X., Wang, X., Boreave, A., George, C., Ding, X., and Wang, X.: Secondary organic aerosol formation from photo-oxidation of toluene with $\mathrm{NO}_{x}$ and $\mathrm{SO}_{2}$ : Chamber simulation with purified air versus urban ambient air as matrix, Atmos. Environ., 150, 67-76, https://doi.org/10.1016/j.atmosenv.2016.11.047, 2017.

Dhammapala, R., Claiborn, C., Jimenez, J., Corkill, J., Gullett, B., Simpson, C., and Paulsen, M.: Emission factors of PAHs, methoxyphenols, levoglucosan, elemental carbon and organic carbon from simulated wheat and Kentucky bluegrass stubble burns, Atmos. Environ., 41, 2660-2669, https://doi.org/10.1016/j.atmosenv.2006.11.023, 2007.

Ding, X., He, Q.-F., Shen, R.-Q., Yu, Q.-Q., Zhang, Y.-Q., Xin, J.-Y., Wen, T.-X., and Wang, X.-M.: Spatial and seasonal variations of isoprene secondary organic aerosol in China: Significant impact of biomass burning during winter, Sci. Rep., 6, 20411, https://doi.org/10.1038/srep20411, 2016a.

Ding, X., Zhang, Y.-Q., He, Q.-F., Yu, Q.-Q., Shen, R.-Q., Zhang, Y., Zhang, Z., Lyu, S.-J., Hu, Q.-H., Wang, Y.-S., Li, L.-F., Song, W., and Wang, X.-M.: Spatial and seasonal variations of secondary organic aerosol from terpenoids over China, J. Geophys. Res.-Atmos., 121, 14661-14678, https://doi.org/10.1002/2016JD025467, 2016b. 
Ding, X., Zhang, Y.-Q., He, Q.-F., Yu, Q.-Q., Wang, J.-Q., Shen, R.-Q., Song, W., Wang, Y.-S., and Wang, X.-M.: Significant increase of aromatics-derived secondary organic aerosol during fall to winter in China, Environ. Sci. Technol., 51, 7432-7441, https://doi.org/10.1021/acs.est.6b06408, 2017.

Du, Q., Zhang, C., Mu, Y., Cheng, Y., Zhang, Y., Liu, C., Song, M., Tian, D., Liu, P., Liu, J., Xue, C., and Ye, C.: An important missing source of atmospheric carbonyl sulfide: Domestic coal combustion, Geophys. Res. Lett., 43, 8720-8727, https://doi.org/10.1002/2016gl070075, 2016.

Duncan, B. N., Bey, I., Chin, M., Mickley, L. J., Fairlie, T. D., Martin, R. V., and Matsueda, H.: Indonesian wildfires of 1997: Impact on tropospheric chemistry, J. Geophys. Res.-Atmos., 108, 4458, https://doi.org/10.1029/2002jd003195, 2003.

Ervens, B., Turpin, B. J., and Weber, R. J.: Secondary organic aerosol formation in cloud droplets and aqueous particles (aqSOA): a review of laboratory, field and model studies, Atmos. Chem. Phys., 11, 11069-11102, https://doi.org/10.5194/acp-1111069-2011, 2011

FAO (Food and Agriculture Organization of the United Nation): Emissions of methane and nitrous oxide from the on-site combustion of crop residues, available at: http://faostat3.fao.org/ browse/G1/GB/E, last access: 6 April 2017.

Ge, S., Xu, Y., and Jia, L.: Secondary organic aerosol formation from ethyne in the presence of $\mathrm{NaCl}$ in a smog chamber, Environ. Chem., 13, 699-710, https://doi.org/10.1071/en15155, 2016.

Ge, S., Xu, Y., and Jia, L.: Secondary organic aerosol formation from propylene irradiations in a chamber study, Atmos. Environ., 157, 146-155, https://doi.org/10.1016/j.atmosenv.2017.03.019, 2017.

Giordano, M. R., Short, D. Z., Hosseini, S., Lichtenberg, W., and Asa-Awuku, A. A.: Changes in droplet surface tension affect the observed hygroscopicity of photochemically aged biomass burning aerosol, Environ. Sci. Technol., 47, 1098010986, https://doi.org/10.1021/es401867j, 2013.

Gómez Alvarez, E., Borras, E., Viidanoja, J., and Hjorth, J.: Unsaturated dicarbonyl products from the $\mathrm{OH}$-initiated photo-oxidation of furan, 2-methylfuran and 3-methylfuran, Atmos. Environ., 43, 1603-1612, https://doi.org/10.1016/j.atmosenv.2008.12.019, 2009.

Grieshop, A. P., Donahue, N. M., and Robinson, A. L.: Laboratory investigation of photochemical oxidation of organic aerosol from wood fires 2: analysis of aerosol mass spectrometer data, Atmos. Chem. Phys., 9, 2227-2240, https://doi.org/10.5194/acp-9-22272009, 2009a.

Grieshop, A. P., Logue, J. M., Donahue, N. M., and Robinson, A. L.: Laboratory investigation of photochemical oxidation of organic aerosol from wood fires 1: measurement and simulation of organic aerosol evolution, Atmos. Chem. Phys., 9, 1263-1277, https://doi.org/10.5194/acp-9-1263-2009, 2009b.

Hall, D., Wu, C. Y., Hsu, Y. M., Stormer, J., Engling, G., Capeto, K., Wang, J., Brown, S., Li, H. W., and Yu, K. M.: PAHs, carbonyls, VOCs and $\mathrm{PM}_{2.5}$ emission factors for pre-harvest burning of Florida sugarcane, Atmos. Environ., 55, 164-172, https://doi.org/10.1016/j.atmosenv.2012.03.034, 2012.

Hatch, L. E., Yokelson, R. J., Stockwell, C. E., Veres, P. R., Simpson, I. J., Blake, D. R., Orlando, J. J., and Barsanti, K. C.: Multi-instrument comparison and compilation of non-methane organic gas emissions from biomass burning and implications for smoke-derived secondary organic aerosol precursors, Atmos. Chem. Phys., 17, 1471-1489, https://doi.org/10.5194/acp17-1471-2017, 2017.

Hayes, P. L., Ortega, A. M., Cubison, M. J., Froyd, K. D., Zhao, Y., Cliff, S. S., Hu, W. W., Toohey, D. W., Flynn, J. H., Lefer, B. L., Grossberg, N., Alvarez, S., Rappenglueck, B., Taylor, J. W., Allan, J. D., Holloway, J. S., Gilman, J. B., Kuster, W. C., De Gouw, J. A., Massoli, P., Zhang, X., Liu, J., Weber, R. J., Corrigan, A. L., Russell, L. M., Isaacman, G., Worton, D. R., Kreisberg, N. M., Goldstein, A. H., Thalman, R., Waxman, E. M., Volkamer, R., Lin, Y. H., Surratt, J. D., Kleindienst, T. E., Offenberg, J. H., Dusanter, S., Griffith, S., Stevens, P. S., Brioude, J., Angevine, W. M., and Jimenez, J. L.: Organic aerosol composition and sources in Pasadena, California, during the 2010 CalNex campaign, J. Geophys. Res.-Atmos., 118, 9233-9257, https://doi.org/10.1002/jgrd.50530, 2013.

Heald, C. L., Kroll, J. H., Jimenez, J. L., Docherty, K. S., DeCarlo, P. F., Aiken, A. C., Chen, Q., Martin, S. T., Farmer, D. K., and Artaxo, P.: A simplified description of the evolution of organic aerosol composition in the atmosphere, Geophys. Res. Lett., 37, L08803, https://doi.org/10.1029/2010g1042737, 2010.

Hennigan, C. J., Miracolo, M. A., Engelhart, G. J., May, A. A., Presto, A. A., Lee, T., Sullivan, A. P., McMeeking, G. R., Coe, H., Wold, C. E., Hao, W.-M., Gilman, J. B., Kuster, W. C., de Gouw, J., Schichtel, B. A., Collett Jr., J. L., Kreidenweis, S. M., and Robinson, A. L.: Chemical and physical transformations of organic aerosol from the photo-oxidation of open biomass burning emissions in an environmental chamber, Atmos. Chem. Phys., 11, 7669-7686, https://doi.org/10.5194/acp11-7669-2011, 2011.

Henry, K. M., Lohaus, T., and Donahue, N. M.: Organic aerosol yields from $\alpha$-pinene oxidation: bridging the gap between firstgeneration yields and aging chemistry, Environ. Sci. Technol., 46, 12347-12354, https://doi.org/10.1021/es302060y, 2012.

Heringa, M. F., DeCarlo, P. F., Chirico, R., Tritscher, T., Dommen, J., Weingartner, E., Richter, R., Wehrle, G., Prévôt, A. S. H., and Baltensperger, U.: Investigations of primary and secondary particulate matter of different wood combustion appliances with a high-resolution time-of-flight aerosol mass spectrometer, Atmos. Chem. Phys., 11, 5945-5957, https://doi.org/10.5194/acp11-5945-2011, 2011.

Hildebrandt, L., Donahue, N. M., and Pandis, S. N.: High formation of secondary organic aerosol from the photooxidation of toluene, Atmos. Chem. Phys., 9, 2973-2986, https://doi.org/10.5194/acp-9-2973-2009, 2009.

Hossain, A., Park, S., Kim, J. S., and Park, K.: Volatility and mixing states of ultrafine particles from biomass burning, J. Hazard. Mater., 205, 189-197, https://doi.org/10.1016/j.jhazmat.2011.12.061, 2012.

Hosseini, S., Urbanski, S. P., Dixit, P., Qi, L., Burling, I. R., Yokelson, R. J., Johnson, T. J., Shrivastava, M., Jung, H. S., Weise, D. R., Miller, J. W., and Cocker, D. R.: Laboratory characterization of PM emissions from combustion of wildland biomass fuels, J. Geophys. Res.-Atmos., 118, 9914-9929, https://doi.org/10.1002/jgrd.50481, 2013.

Huang, R. J., Zhang, Y. L., Bozzetti, C., Ho, K. F., Cao, J. J., Han, Y. M., Daellenbach, K. R., Slowik, J. G., Platt, S. M., Canonaco, F., Zotter, P., Wolf, R., Pieber, S. M., Bruns, E. A., Crippa, M., Ciarelli, G., Piazzalunga, A., Schwikowski, 
M., Abbaszade, G., Schnelle-Kreis, J., Zimmermann, R., An, Z. S., Szidat, S., Baltensperger, U., El Haddad, I., and Prevot, A. S. H.: High secondary aerosol contribution to particulate pollution during haze events in China, Nature, 514, 218-222, https://doi.org/10.1038/nature13774, 2014.

Huang, X., Ding, A., Liu, L., Liu, Q., Ding, K., Niu, X., Nie, W., Xu, Z., Chi, X., Wang, M., Sun, J., Guo, W., and Fu, C.: Effects of aerosol-radiation interaction on precipitation during biomassburning season in East China, Atmos. Chem. Phys., 16, 1006310082, https://doi.org/10.5194/acp-16-10063-2016, 2016.

Huang, Y., Shen, H. Z., Chen, Y. L., Zhong, Q. R., Chen, H., Wang, R., Shen, G. F., Liu, J. F., Li, B. G., and Tao, S.: Global organic carbon emissions from primary sources from 1960 to 2009, Atmos. Environ., 122, 505-512, https://doi.org/10.1016/j.atmosenv.2015.10.017, 2015.

Huang, Z., Zhang, Y., Yan, Q., Zhang, Z., and Wang, X.: Realtime monitoring of respiratory absorption factors of volatile organic compounds in ambient air by proton transfer reaction timeof-flight mass spectrometry, J. Hazard. Mater., 320, 547-555, https://doi.org/10.1016/j.jhazmat.2016.08.064, 2016.

Huffman, J. A., Docherty, K. S., Mohr, C., Cubison, M. J., Ulbrich, I. M., Ziemann, P. J., Onasch, T. B., and Jimenez, J. L.: Chemically-resolved volatility measurements of organic aerosol from different sources, Environ. Sci. Technol., 43, 5351-5357, https://doi.org/10.1021/es803539d, 2009.

Jathar, S. H., Gordon, T. D., Hennigan, C. J., Pye, H. O. T., Pouliot, G., Adams, P. J., Donahue, N. M., and Robinson, A. L.: Unspeciated organic emissions from combustion sources and their influence on the secondary organic aerosol budget in the United States, P. Natl. Acad. Sci. USA, 111, 10473-10478, https://doi.org/10.1073/pnas.1323740111, 2014.

Jia, L. and $\mathrm{Xu}, \mathrm{Y} .:$ Ozone and secondary organic aerosol formation from Ethylene- $\mathrm{NO}_{x}-\mathrm{NaCl}$ irradiations under different relative humidity conditions, J. Atmos. Chem., 73, 81-100, https://doi.org/10.1007/s10874-015-9317-1, 2016.

Jolleys, M. D., Coe, H., McFiggans, G., Capes, G., Allan, J. D., Crosier, J., Williams, P. I., Allen, G., Bower, K. N., Jimenez, J. L., Russell, L. M., Grutter, M., and Baumgardner, D.: Characterizing the aging of biomass burning organic aerosol by use of mixing ratios: a meta-analysis of four regions, Environ. Sci. Technol., 46, 13093-13102, https://doi.org/10.1021/es302386v, 2012.

Kim Oanh, N. T., Ly, B. T., Tipayarom, D., Manandhar, B. R., Prapat, P., Simpson, C. D., and Sally Liu, L. J.: Characterization of particulate matter emission from open burning of rice straw, Atmos. Environ., 45, 493-502, https://doi.org/10.1016/j.atmosenv.2010.09.023, 2011.

Kim Oanh, N. T., Tipayarom, A., Bich, T. L., Tipayarom, D., Simpson, C. D., Hardie, D., and Sally Liu, L. J.: Characterization of gaseous and semi-volatile organic compounds emitted from field burning of rice straw, Atmos. Environ., 119, 182-191, https://doi.org/10.1016/j.atmosenv.2015.08.005, 2015.

Kirchstetter, T. W. and Novakov, T.: Controlled generation of black carbon particles from a diffusion flame and applications in evaluating black carbon measurement methods, Atmos. Environ., 41, 1874-1888, https://doi.org/10.1016/j.atmosenv.2006.10.067, 2007.

Koren, I., Kaufman, Y. J., Remer, L. A., and Martins, J. V.: Measurement of the effect of Amazon smoke on inhibition of cloud formation, Science, 303, 1342-1345, https://doi.org/10.1126/science.1089424, 2004.

Kroll, J. H., Donahue, N. M., Jimenez, J. L., Kessler, S. H., Canagaratna, M. R., Wilson, K. R., Altieri, K. E., Mazzoleni, L. R., Wozniak, A. S., and Bluhm, H.: Carbon oxidation state as a metric for describing the chemistry of atmospheric organic aerosol, Nat. Chem., 3, 133-139, https://doi.org/10.1038/nchem.948, 2011.

Lambe, A. T., Ahern, A. T., Williams, L. R., Slowik, J. G., Wong, J. P. S., Abbatt, J. P. D., Brune, W. H., Ng, N. L., Wright, J. P., Croasdale, D. R., Worsnop, D. R., Davidovits, P., and Onasch, T. B.: Characterization of aerosol photooxidation flow reactors: heterogeneous oxidation, secondary organic aerosol formation and cloud condensation nuclei activity measurements, Atmos. Meas. Tech., 4, 445-461, https://doi.org/10.5194/amt-4445-2011, 2011.

Laskin, A., Laskin, J., and Nizkorodov, S. A.: Chemistry of atmospheric brown carbon, Chem. Rev., 115, 4335-4382, https://doi.org/10.1021/cr5006167, 2015.

Li, C., Ma, Z., Chen, J., Wang, X., Ye, X., Wang, L., Yang, X., Kan, H., Donaldson, D. J., and Mellouki, A.: Evolution of biomass burning smoke particles in the dark, Atmos. Environ., 120, 244252, https://doi.org/10.1016/j.atmosenv.2015.09.003, 2015.

Li, C., Hu, Y., Zhang, F., Chen, J., Ma, Z., Ye, X., Yang, X., Wang, L., Tang, X., Zhang, R., Mu, M., Wang, G., Kan, H., Wang, X., and Mellouki, A.: Multi-pollutant emissions from the burning of major agricultural residues in China and the related health-economic effects, Atmos. Chem. Phys., 17, 4957-4988, https://doi.org/10.5194/acp-17-4957-2017, 2017.

Li, J., Bo, Y., and Xie, S. D.: Estimating emissions from crop residue open burning in China based on statistics and MODIS fire products, J. Environ. Sci., 44, 158-170, https://doi.org/10.1016/j.jes.2015.08.024, 2016.

Li, Q., Li, X. H., Jiang, J. K., Duan, L., Ge, S., Zhang, Q., Deng, J. G., Wang, S. X., and Hao, J. M.: Semi-coke briquettes: towards reducing emissions of primary $\mathrm{PM}_{2.5}$, particulate carbon, and carbon monoxide from household coal combustion in China, Sci. Rep., 6, 19306, https://doi.org/10.1038/srep19306, 2016.

Li, X. G., Wang, S. X., Duan, L., Hao, J., Li, C., Chen, Y. S., and Yang, L.: Particulate and trace gas emissions from open burning of wheat straw and corn stover in China, Environ. Sci. Technol., 41, 6052-6058, https://doi.org/10.1021/es0705137, 2007.

Li, X. H., Wang, S. X., Duan, L., and Hao, J. M.: Characterization of non-methane hydrocarbons emitted from open burning of wheat straw and corn stover in China, Environ. Res. Lett., 4, 044015, https://doi.org/10.1088/1748-9326/4/4/044015, 2009.

Liao, C. P., Wu, C. Z., Yan, Y. J., and Huang, H. T.: Chemical elemental characteristics of biomass fuels in China, Biomass Bioenergy, 27, 119-130, https://doi.org/10.1016/j.biombioe.2004.01.002, 2004.

Lim, Y. B., Tan, Y., and Turpin, B. J.: Chemical insights, explicit chemistry, and yields of secondary organic aerosol from $\mathrm{OH}$ radical oxidation of methylglyoxal and glyoxal in the aqueous phase, Atmos. Chem. Phys., 13, 8651-8667, https://doi.org/10.5194/acp-13-8651-2013, 2013.

Lipsky, E. M. and Robinson, A. L.: Effects of dilution on fine particle mass and partitioning of semivolatile organics in diesel exhaust and wood smoke, Environ. Sci. Technol., 40, 155-162, https://doi.org/10.1021/es050319p, 2006. 
Liu, C., Zhang, C., Mu, Y., Liu, J., and Zhang, Y.: Emission of volatile organic compounds from domestic coal stove with the actual alternation of flaming and smoldering combustion processes, Environ. Pollut., 221, 385-391, https://doi.org/10.1016/j.envpol.2016.11.089, 2017.

Liu, J., Mauzerall, D. L., Chen, Q., Zhang, Q., Song, Y., Peng, W., Klimont, Z., Qiu, X., Zhang, S., Hu, M., Lin, W., Smith, K. R., and Zhu, T.: Air pollutant emissions from Chinese households: A major and underappreciated ambient pollution source, P. Natl. Acad. Sci. USA, 113, 7756-7761, https://doi.org/10.1073/pnas.1604537113, 2016.

Liu, T., Wang, X., Deng, W., Hu, Q., Ding, X., Zhang, Y., He, Q., Zhang, Z., Lü, S., Bi, X., Chen, J., and Yu, J.: Secondary organic aerosol formation from photochemical aging of lightduty gasoline vehicle exhausts in a smog chamber, Atmos. Chem. Phys., 15, 9049-9062, https://doi.org/10.5194/acp-159049-2015, 2015.

Liu, X. X., Zhang, Y., Huey, L. G., Yokelson, R. J., Wang, Y., Jimenez, J. L., Campuzano-Jost, P., Beyersdorf, A. J., Blake, D. R., Choi, Y., St Clair, J. M., Crounse, J. D., Day, D. A., Diskin, G. S., Fried, A., Hall, S. R., Hanisco, T. F., King, L. E., Meinardi, S., Mikoviny, T., Palm, B. B., Peischl, J., Perring, A. E., Pollack, I. B., Ryerson, T. B., Sachse, G., Schwarz, J. P., Simpson, I. J., Tanner, D. J., Thornhill, K. L., Ullmann, K., Weber, R. J., Wennberg, P. O., Wisthaler, A., Wolfe, G. M., and Ziemba, L. D.: Agricultural fires in the southeastern US during SEAC ${ }^{4} \mathrm{RS}$ : Emissions of trace gases and particles and evolution of ozone, reactive nitrogen, and organic aerosol, J. Geophys. Res.-Atmos., 121, 7383-7414, https://doi.org/10.1002/2016jd025040, 2016.

Martin, M., Tritscher, T., Juranyi, Z., Heringa, M. F., Sierau, B., Weingartner, E., Chirico, R., Gysel, M., Prevot, A. S. H., Baltensperger, U., and Lohmann, U.: Hygroscopic properties of fresh and aged wood burning particles, J. Aerosol Sci., 56, 1529, https://doi.org/10.1016/j.jaerosci.2012.08.006, 2013.

May, A. A., Levin, E. J. T., Hennigan, C. J., Riipinen, I., Lee, T., Collett, J. L., Jr., Jimenez, J. L., Kreidenweis, S. M., and Robinson, A. L.: Gas-particle partitioning of primary organic aerosol emissions: 3. Biomass burning, J. Geophys. Res.-Atmos., 118, 11327-11338, https://doi.org/10.1002/jgrd.50828, 2013.

May, A. A., Lee, T., McMeeking, G. R., Akagi, S., Sullivan, A. P., Urbanski, S., Yokelson, R. J., and Kreidenweis, S. M.: Observations and analysis of organic aerosol evolution in some prescribed fire smoke plumes, Atmos. Chem. Phys., 15, 6323-6335, https://doi.org/10.5194/acp-15-6323-2015, 2015.

McMurry, P. H. and Grosjean, D.: Gas and aerosol wall losses in Teflon film smog chambers, Environ. Sci. Technol., 19, 11761182, https://doi.org/10.1021/es00142a006, 1985.

Müller, M., Anderson, B. E., Beyersdorf, A. J., Crawford, J. H., Diskin, G. S., Eichler, P., Fried, A., Keutsch, F. N., Mikoviny, T., Thornhill, K. L., Walega, J. G., Weinheimer, A. J., Yang, M., Yokelson, R. J., and Wisthaler, A.: In situ measurements and modeling of reactive trace gases in a small biomass burning plume, Atmos. Chem. Phys., 16, 3813-3824, https://doi.org/10.5194/acp-16-3813-2016, 2016.

Nakao, S., Clark, C., Tang, P., Sato, K., and Cocker III, D.: Secondary organic aerosol formation from phenolic compounds in the absence of $\mathrm{NO}_{x}$, Atmos. Chem. Phys., 11, 10649-10660, https://doi.org/10.5194/acp-11-10649-2011, 2011.
NBSPRC (National bureau of statistics of people's republic of China): China Energy Statistical Yearbook 2013, China Stat. Press, Beijing, 2014.

NBSPRC (National bureau of statistics of people's republic of China): The statistical communiqu on national economy and social development in 2015, available at: http://www.stats.gov. cn/tjsj/zxfb/201602/t20160229_1323991.html (last access: 27 September 2017), 2015.

Ng, N. L., Kroll, J. H., Chan, A. W. H., Chhabra, P. S., Flagan, R. C., and Seinfeld, J. H.: Secondary organic aerosol formation from $m$-xylene, toluene, and benzene, Atmos. Chem. Phys., 7, 3909-3922, https://doi.org/10.5194/acp-7-3909-2007, 2007.

Ng, N. L., Canagaratna, M. R., Zhang, Q., Jimenez, J. L., Tian, J., Ulbrich, I. M., Kroll, J. H., Docherty, K. S., Chhabra, P. S., Bahreini, R., Murphy, S. M., Seinfeld, J. H., Hildebrandt, L., Donahue, N. M., DeCarlo, P. F., Lanz, V. A., Prévôt, A. S. H., Dinar, E., Rudich, Y., and Worsnop, D. R.: Organic aerosol components observed in Northern Hemispheric datasets from Aerosol Mass Spectrometry, Atmos. Chem. Phys., 10, 46254641, https://doi.org/10.5194/acp-10-4625-2010, 2010.

Ng, N. L., Canagaratna, M. R., Jimenez, J. L., Chhabra, P. S., Seinfeld, J. H., and Worsnop, D. R.: Changes in organic aerosol composition with aging inferred from aerosol mass spectra, Atmos. Chem. Phys., 11, 6465-6474, https://doi.org/10.5194/acp11-6465-2011, 2011a.

Ng, N. L., Canagaratna, M. R., Jimenez, J. L., Zhang, Q., Ulbrich, I. M., and Worsnop, D. R.: Real-Time Methods for estimating organic cComponent mass concentrations from aerosol mass spectrometer data, Environ. Sci. Technol., 45, 910-916, https://doi.org/10.1021/es102951k, 2011b.

Ni, H. Y., Han, Y. M., Cao, J. J., Chen, L. W. A., Tian, J., Wang, X. L., Chow, J. C., Watson, J. G., Wang, Q. Y., Wang, P., Li, H., and Huang, R. J.: Emission characteristics of carbonaceous particles and trace gases from open burning of crop residues in China, Atmos. Environ., 123, 399-406, https://doi.org/10.1016/j.atmosenv.2015.05.007, 2015.

Niu, H. Y., Cheng, W. J., Hu, W., and Pian, W.: Characteristics of individual particles in a severe short-period haze episode induced by biomass burning in Beijing, Atmos. Pollut. Res., 7, 10721081, https://doi.org/10.1016/j.apr.2016.05.011, 2016.

Ortega, A. M., Day, D. A., Cubison, M. J., Brune, W. H., Bon, D., de Gouw, J. A., and Jimenez, J. L.: Secondary organic aerosol formation and primary organic aerosol oxidation from biomassburning smoke in a flow reactor during FLAME-3, Atmos. Chem. Phys., 13, 11551-11571, https://doi.org/10.5194/acp-1311551-2013, 2013.

Pan, X., Kanaya, Y., Tanimoto, H., Inomata, S., Wang, Z., Kudo, S., and Uno, I.: Examining the major contributors of ozone pollution in a rural area of the Yangtze River Delta region during harvest season, Atmos. Chem. Phys., 15, 6101-6111, https://doi.org/10.5194/acp-15-6101-2015, 2015.

Presto, A. A., Miracolo, M. A., Kroll, J. H., Worsnop, D. R., Robinson, A. L., and Donahue, N. M.: Intermediatevolatility organic compounds: A potential source of ambient oxidized organic aerosol, Environ. Sci. Technol., 43, 4744-4749, https://doi.org/10.1021/es803219q, 2009.

Real, E., Law, K. S., Weinzierl, B., Fiebig, M., Petzold, A., Wild, O., Methven, J., Arnold, S., Stohl, A., Huntrieser, H., Roiger, A., Schlager, H., Stewart, D., Avery, M., Sachse, G., Browell, 
E., Ferrare, R., and Blake, D.: Processes influencing ozone levels in Alaskan forest fire plumes during long-range transport over the North Atlantic, J. Geophys. Res.-Atmos., 112, D10S41, https://doi.org/10.1029/2006jd007576, 2007.

Robinson, A. L., Donahue, N. M., Shrivastava, M. K., Weitkamp, E. A., Sage, A. M., Grieshop, A. P., Lane, T. E., Pierce, J. R., and Pandis, S. N.: Rethinking organic aerosols: semivolatile emissions and photochemical aging, Science, 315, 1259-1262, https://doi.org/10.1126/science.1133061, 2007.

Sanchis, E., Ferrer, M., Calvet, S., Coscolla, C., Yusa, V., and Cambra-Lopez, M.: Gaseous and particulate emission profiles during controlled rice straw burning, Atmos. Environ., 98, 2531, https://doi.org/10.1016/j.atmosenv.2014.07.062, 2014.

Schmid, O., Artaxo, P., Arnott, W. P., Chand, D., Gatti, L. V., Frank, G. P., Hoffer, A., Schnaiter, M., and Andreae, M. O.: Spectral light absorption by ambient aerosols influenced by biomass burning in the Amazon Basin. I: Comparison and field calibration of absorption measurement techniques, Atmos. Chem. Phys., 6, 3443-3462, https://doi.org/10.5194/acp-6-3443-2006, 2006.

Schmid, O., Karg, E., Hagen, D. E., Whitefield, P. D., and Ferron, G. A.: On the effective density of non-spherical particles as derived from combined measurements of aerodynamic and mobility equivalent size, J. Aerosol Sci., 38, 431-443, https://doi.org/10.1016/j.jaerosci.2007.01.002, 2007.

Shahid, I., Kistler, M., Mukhtar, A., Cruz, C. R. S., Bauer, H., and Puxbaum, H.: Chemical composition of particles from traditional burning of Pakistani wood species, Atmos. Environ., 121, 35-41, https://doi.org/10.1016/j.atmosenv.2015.01.041, 2015.

Shakya, K. M. and Griffin, R. J.: Secondary organic aerosol from photooxidation of polycyclic aromatic hydrocarbons, Environ. Sci. Technol., 44, 8134-8139, https://doi.org/10.1021/es1019417, 2010.

Shrivastava, M., Easter, R. C., Liu, X. H., Zelenyuk, A., Singh, B., Zhang, K., Ma, P. L., Chand, D., Ghan, S., Jimenez, J. L., Zhang, Q., Fast, J., Rasch, P. J., and Tiitta, P.: Global transformation and fate of SOA: Implications of low-volatility SOA and gas-phase fragmentation reactions, J. Geophys. Res.-Atmos., 120, 41694195, https://doi.org/10.1002/2014jd022563, 2015.

Spracklen, D. V., Jimenez, J. L., Carslaw, K. S., Worsnop, D. R., Evans, M. J., Mann, G. W., Zhang, Q., Canagaratna, M. R., Allan, J., Coe, H., McFiggans, G., Rap, A., and Forster, P.: Aerosol mass spectrometer constraint on the global secondary organic aerosol budget, Atmos. Chem. Phys., 11, 12109-12136, https://doi.org/10.5194/acp-11-12109-2011, 2011.

Stockwell, C. E., Yokelson, R. J., Kreidenweis, S. M., Robinson, A. L., DeMott, P. J., Sullivan, R. C., Reardon, J., Ryan, K. C., Griffith, D. W. T., and Stevens, L.: Trace gas emissions from combustion of peat, crop residue, domestic biofuels, grasses, and other fuels: configuration and Fourier transform infrared (FTIR) component of the fourth Fire Lab at Missoula Experiment (FLAME-4), Atmos. Chem. Phys., 14, 9727-9754, https://doi.org/10.5194/acp-14-9727-2014, 2014.

Stockwell, C. E., Veres, P. R., Williams, J., and Yokelson, R. J.: Characterization of biomass burning emissions from cooking fires, peat, crop residue, and other fuels with high-resolution proton-transfer-reaction time-of-flight mass spectrometry, Atmos. Chem. Phys., 15, 845-865, https://doi.org/10.5194/acp-15845-2015, 2015.
Stockwell, C. E., Christian, T. J., Goetz, J. D., Jayarathne, T., Bhave, P. V., Praveen, P. S., Adhikari, S., Maharjan, R., DeCarlo, P. F., Stone, E. A., Saikawa, E., Blake, D. R., Simpson, I. J., Yokelson, R. J., and Panday, A. K.: Nepal Ambient Monitoring and Source Testing Experiment (NAMaSTE): emissions of trace gases and light-absorbing carbon from wood and dung cooking fires, garbage and crop residue burning, brick kilns, and other sources, Atmos. Chem. Phys., 16, 11043-11081, https://doi.org/10.5194/acp-16-11043-2016, 2016.

Streets, D. G., Yarber, K. F., Woo, J. H., and Carmichael, G. R.: Biomass burning in Asia: Annual and seasonal estimates and atmospheric emissions, Global Biogeochem. Cy., 17, 1099, https://doi.org/10.1029/2003gb002040, 2003.

Takekawa, H., Minoura, H., and Yamazaki, S.: Temperature dependence of secondary organic aerosol formation by photooxidation of hydrocarbons, Atmos. Environ., 37, 3413-3424, https://doi.org/10.1016/s1352-2310(03)00359-5, 2003.

Tariq, S., ul-Haq, Z., and Ali, M.: Satellite and ground-based remote sensing of aerosols during intense haze event of October 2013 over lahore, Pakistan, Asia-Pac, J. Atmos. Sci., 52, 25-33, https://doi.org/10.1007/s13143-015-0084-3, 2016.

Tkacik, D. S., Robinson, E. S., Ahern, A., Saleh, R., Stockwell, C., Veres, P., Simpson, I. J., Meinardi, S., Blake, D. R., Yokelson, R. J., Presto, A. A., Sullivan, R. C., Donahue, N. M., and Robinson, A. L.: A dual-chamber method for quantifying the effects of atmospheric perturbations on secondary organic aerosol formation from biomass burning emissions, J. Geophys. Res.-Atmos., 122, 6043-6058, https://doi.org/10.1002/2016JD025784, 2017.

Thompson, A. M., Witte, J. C., Hudson, R. D., Guo, H., Herman, J. R., and Fujiwara, M.: Tropical tropospheric ozone and biomass burning, Science, 291, 2128-2132, https://doi.org/10.1126/science.291.5511.2128, 2001.

Tian, H., Zhao, D., and Wang, Y.: Emission inventories of atmospheric pollutants discharged from biomass burning in China, Acta Sci. Circumst., 31, 349-357, 2011 (in Chinese).

Tiitta, P., Leskinen, A., Hao, L., Yli-Pirilä, P., Kortelainen, M., Grigonyte, J., Tissari, J., Lamberg, H., Hartikainen, A., Kuuspalo, K., Kortelainen, A.-M., Virtanen, A., Lehtinen, K. E. J., Komppula, M., Pieber, S., Prévôt, A. S. H., Onasch, T. B., Worsnop, D. R., Czech, H., Zimmermann, R., Jokiniemi, J., and Sippula, O.: Transformation of logwood combustion emissions in a smog chamber: formation of secondary organic aerosol and changes in the primary organic aerosol upon daytime and nighttime aging, Atmos. Chem. Phys., 16, 13251-13269, https://doi.org/10.5194/acp-16-13251-2016, 2016.

Tsigaridis, K., Daskalakis, N., Kanakidou, M., Adams, P. J., Artaxo, P., Bahadur, R., Balkanski, Y., Bauer, S. E., Bellouin, N., Benedetti, A., Bergman, T., Berntsen, T. K., Beukes, J. P., Bian, H., Carslaw, K. S., Chin, M., Curci, G., Diehl, T., Easter, R. C., Ghan, S. J., Gong, S. L., Hodzic, A., Hoyle, C. R., Iversen, T., Jathar, S., Jimenez, J. L., Kaiser, J. W., Kirkevåg, A., Koch, D., Kokkola, H., Lee, Y. H., Lin, G., Liu, X., Luo, G., Ma, X., Mann, G. W., Mihalopoulos, N., Morcrette, J.-J., Müller, J.-F., Myhre, G., Myriokefalitakis, S., Ng, N. L., O’Donnell, D., Penner, J. E., Pozzoli, L., Pringle, K. J., Russell, L. M., Schulz, M., Sciare, J., Seland, Ø., Shindell, D. T., Sillman, S., Skeie, R. B., Spracklen, D., Stavrakou, T., Steenrod, S. D., Takemura, T., Tiitta, P., Tilmes, S., Tost, H., van Noije, T., van Zyl, P. G., von Salzen, K., Yu, F., Wang, Z., Wang, Z., Zaveri, R. A., Zhang, H., 
Zhang, K., Zhang, Q., and Zhang, X.: The AeroCom evaluation and intercomparison of organic aerosol in global models, Atmos. Chem. Phys., 14, 10845-10895, https://doi.org/10.5194/acp-1410845-2014, 2014.

Wang, H., Lou, S., Huang, C., Qiao, L., Tang, X., Chen, C., Zeng, L., Wang, Q., Zhou, M., Lu, S., and Yu, X.: Source profiles of volatile organic compounds from biomass burning in Yangtze River Delta, China, Aerosol Air Qual. Res., 14, 818828, https://doi.org/10.4209/aaqr.2013.05.0174, 2014.

Wang, $\mathrm{X}$. and $\mathrm{Wu}, \mathrm{T}$.: Release of isoprene and monoterpenes during the aerobic decomposition of orange wastes from laboratory incubation experiments, Environ. Sci. Technol., 42, 3265-3270, https://doi.org/10.1021/es702999j, 2008.

Wang, X., Liu, T., Bernard, F., Ding, X., Wen, S., Zhang, Y., Zhang, Z., He, Q., Lü, S., Chen, J., Saunders, S., and Yu, J.: Design and characterization of a smog chamber for studying gas-phase chemical mechanisms and aerosol formation, Atmos. Meas. Tech., 7, 301-313, https://doi.org/10.5194/amt-7301-2014, 2014.

Ward, D. E., Susott, R. A., Kauffman, J. B., Babbitt, R. E., Cummings, D. L., Dias, B., Holben, B. N., Kaufman, Y. J., Rasmussen, R. A., and Setzer, A. W.: Smoke and fire characteristics for cerrado and deforestation burns in Brazil: BASEB Experiment, J. Geophys. Res.-Atmos., 97, 14601-14619, https://doi.org/10.1029/92JD01218, 1992.

Weimer, S., Alfarra, M. R., Schreiber, D., Mohr, M., Prevot, A. S. H., and Baltensperger, U.: Organic aerosol mass spectral signatures from wood-burning emissions: Influence of burning conditions and wood type, J. Geophys. Res.-Atmos., 113, D10304, https://doi.org/10.1029/2007jd009309, 2008.

Weitkamp, E. A., Sage, A. M., Pierce, J. R., Donahue, N. M., and Robinson, A. L.: Organic aerosol formation from photochemical oxidation of diesel exhaust in a smog chamber, Environ. Sci. Technol., 41, 6969-6975, https://doi.org/10.1021/es070193r, 2007.

Yee, L. D., Kautzman, K. E., Loza, C. L., Schilling, K. A., Coggon, M. M., Chhabra, P. S., Chan, M. N., Chan, A. W. H., Hersey, S. P., Crounse, J. D., Wennberg, P. O., Flagan, R. C., and Seinfeld, J. H.: Secondary organic aerosol formation from biomass burning intermediates: phenol and methoxyphenols, Atmos. Chem. Phys., 13, 8019-8043, https://doi.org/10.5194/acp13-8019-2013, 2013.

Yi, Z. G., Wang, X. M., Sheng, G. Y., Zhang, D. Q., Zhou, G. Y., and Fu, J. M.: Soil uptake of carbonyl sulfide in subtropical forests with different successional stages in south China, J. Geophys. Res.-Atmos., 112, D08302, https://doi.org/10.1029/2006jd008048, 2007.

Yokelson, R. J., Christian, T. J., Karl, T. G., and Guenther, A.: The tropical forest and fire emissions experiment: laboratory fire measurements and synthesis of campaign data, Atmos. Chem. Phys., 8, 3509-3527, https://doi.org/10.5194/acp-8-3509-2008, 2008 .
Yokelson, R. J., Burling, I. R., Urbanski, S. P., Atlas, E. L., Adachi, K., Buseck, P. R., Wiedinmyer, C., Akagi, S. K., Toohey, D. W., and Wold, C. E.: Trace gas and particle emissions from open biomass burning in Mexico, Atmos. Chem. Phys., 11, 67876808, https://doi.org/10.5194/acp-11-6787-2011, 2011.

Zhang, H., Ye, X., Cheng, T., Chen, J., Yang, X., Wang, L., and Zhang, R.: A laboratory study of agricultural crop residue combustion in China: Emission factors and emission inventory, Atmos. Environ., 42, 8432-8441, https://doi.org/10.1016/j.atmosenv.2008.08.015, 2008.

Zhang, H., Hu, D., Chen, J., Ye, X., Wang, S. X., Hao, J. M., Wang, L., Zhang, R., and An, Z.: Particle size distribution and polycyclic aromatic hydrocarbons emissions from agricultural crop residue burning, Environ. Sci. Technol., 45, 5477-5482, https://doi.org/10.1021/es1037904, 2011.

Zhang, Q., Jimenez, J. L., Canagaratna, M. R., Ulbrich, I. M., $\mathrm{Ng}$, N. L., Worsnop, D. R., and Sun, Y. L.: Understanding atmospheric organic aerosols via factor analysis of aerosol mass spectrometry: a review, Anal. Bioanal. Chem., 401, 3045-3067, https://doi.org/10.1007/s00216-011-5355-y, 2011.

Zhang, Y. L., Guo, H., Wang, X. M., Simpson, I. J., Barletta, B., Blake, D. R., Meinardi, S., Rowland, F. S., Cheng, H. R., Saunders, S. M., and Lam, S. H. M.: Emission patterns and spatiotemporal variations of halocarbons in the Pearl River Delta region, southern China, J. Geophys. Res.-Atmos., 115, D15309, https://doi.org/10.1029/2009jd013726, 2010.

Zhang, Y. L., Wang, X. M., Blake, D. R., Li, L. F., Zhang, Z., Wang, S. Y., Guo, H., Lee, F. S. C., Gao, B., Chan, L. Y., Wu, D., and Rowland, F. S.: Aromatic hydrocarbons as ozone precursors before and after outbreak of the 2008 financial crisis in the Pearl River Delta region, south China, J. Geophys. Res.-Atmos., 117, D15306, https://doi.org/10.1029/2011jd017356, 2012.

Zhao, Y. L., Hennigan, C. J., May, A. A., Tkacik, D. S., de Gouw, J. A., Gilman, J. B., Kuster, W. C., Borbon, A., and Robinson, A. L.: Intermediate-volatility organic compounds: A large source of secondary organic aerosol, Environ. Sci. Technol., 48, 1374313750, https://doi.org/10.1021/es5035188, 2014.

Zhu, Y. H., Yang, L. X., Chen, J. M., Wang, X. F., Xue, L. K., Sui, X., Wen, L., Xu, C. H., Yao, L., Zhang, J. M., Shao, M., Lu, S. H., and Wang, W. X.: Characteristics of ambient volatile organic compounds and the influence of biomass burning at a rural site in Northern China during summer 2013, Atmos. Environ., 124, 156-165, https://doi.org/10.1016/j.atmosenv.2015.08.097, 2016. 